Provided for non-commercial research and education use. Not for reproduction, distribution or commercial use.

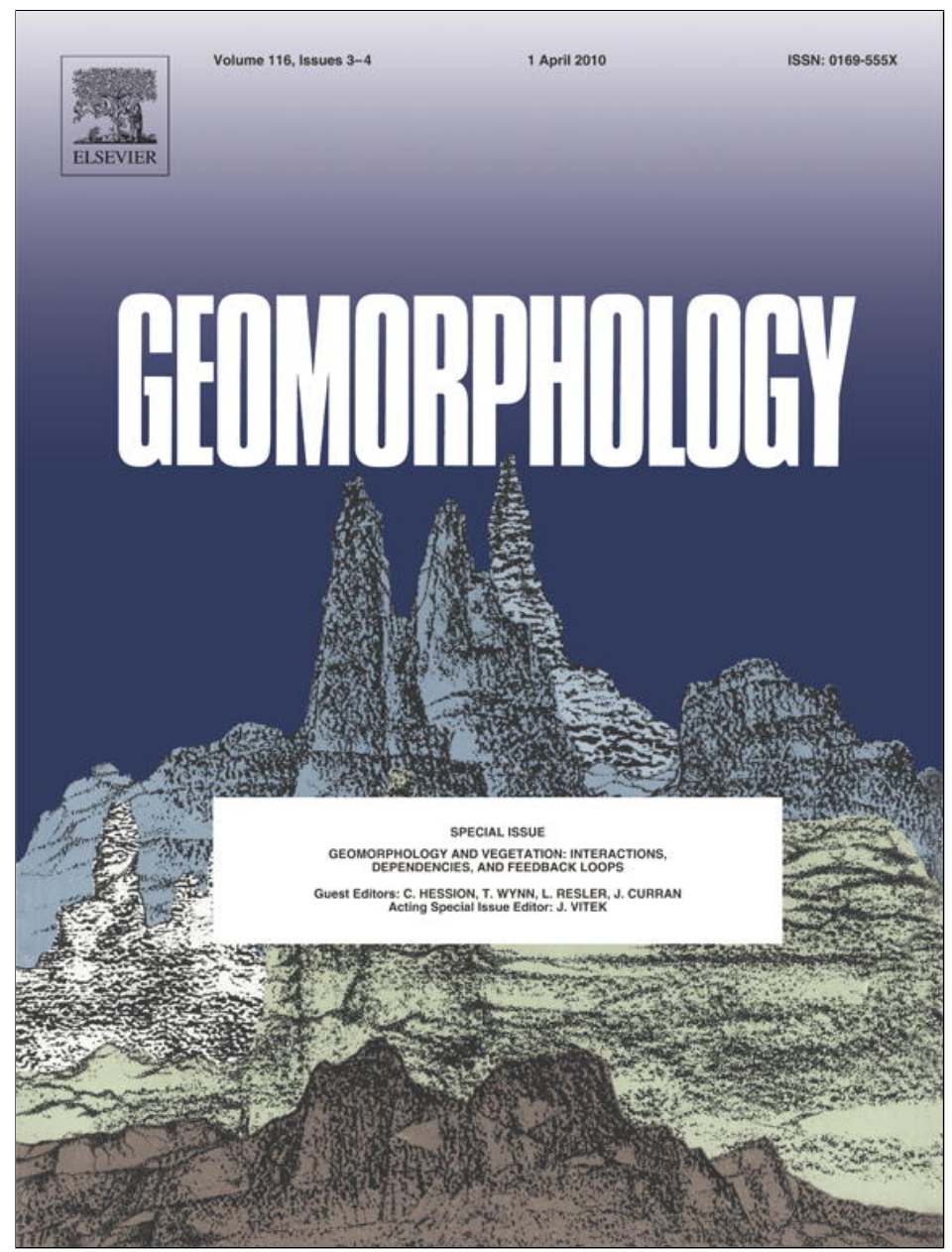

This article appeared in a journal published by Elsevier. The attached copy is furnished to the author for internal non-commercial research and education use, including for instruction at the authors institution and sharing with colleagues.

Other uses, including reproduction and distribution, or selling or licensing copies, or posting to personal, institutional or third party websites are prohibited.

In most cases authors are permitted to post their version of the article (e.g. in Word or Tex form) to their personal website or institutional repository. Authors requiring further information regarding Elsevier's archiving and manuscript policies are encouraged to visit:

http://www.elsevier.com/copyright 


\title{
Logjam controls on channel:floodplain interactions in wooded catchments and their role in the formation of multi-channel patterns
}

\author{
D.A. Sear ${ }^{\text {a,* }}$, C.E. Millington ${ }^{\text {b }}$, D.R. Kitts ${ }^{c}$, R. Jeffries ${ }^{d}$ \\ a School of Geography, University of Southampton, Highfield, Southampton, SO17 1BJ, UK \\ ${ }^{\mathrm{b}}$ OPENspace Research Centre, Edinburgh College of Art, Lauriston Place, Edinburgh, EH3 9DF, UK \\ c AECOM, 5th Floor, 2 City Walk, Leeds, West Yorkshire, LS11 9AR, UK \\ d Scottish Environment Protection Agency, Clearwater House, Heriot Watt Research Park, Avenue North, Riccarton, Edinburgh, EH14 4AP, UK
}

\section{A R T I C L E I N F O}

\section{Article history:}

Received 1 June 2009

Received in revised form 7 August 2009

Accepted 18 November 2009

Available online 2 December 2009

\section{Keywords:}

Large wood

Forested floodplain

Multi-channel patterns

Floodplain channels

Logjams

\begin{abstract}
A B S T R A C T
The role of wood in the formation and maintenance of complex dynamic floodplain surfaces is important and to date has received relatively limited attention compared to in-channel habitat processes. This paper explores the role of logjams as important agents of channel:floodplain interaction. We draw on a specific case study as well as examples from the literature to show that although the processes of interaction differ, the resulting dynamic floodplain patchwork is a common feature of rivers with logjams. In addition, we contend that the presence of logjams is an important factor in the evolution and maintenance of multiple channel patterns in both montane and lowland river environments. These observations have important implications for the definition of reference targets for river restoration.

The specific results of this research show:

1) The presence of a range of types of multiple channel network dissecting the floodplains of low order channels that are strongly associated with the presence of logjams.

2) The relatively rapid formation of floodplain channels following logjam formation.

3) The dynamic nature of logjams within headwater channels on both seasonal and annual timescales that lead to a highly dynamic habitat mosaic on the floodplain surface.

4) An increased frequency of overbank flooding and high rates of floodplain sediment accumulation upstream of logjams and along floodplain channel networks that create the complex topography observed in the case study forested floodplains.
\end{abstract}

(C) 2009 Elsevier B.V. All rights reserved.

\section{Introduction}

In-channel logjams are a key mechanism by which the channel and floodplain environments are connected at the reach scale. In small, temperate, lowland forest floodplain systems the ratio of bankfull channel width to large wood length is small, typically 0.6 (Piégay and Gurnell, 1997), so wood within the channel tends to form assemblages or complete jams that alter channel morphology (Gregory et al., 1985; Piégay and Gurnell, 1997; Gurnell and Sweet, 1998). Large wood within the channel increases flow resistance (Gippel, 1995; Abbe and Montgomery, 1996; Montgomery and Buffington, 1997; Manners and Doyle, 2008) resulting in local accumulations of inorganic and organic matter that influence channel capacity (Jeffries et al., 2003). Logjams trap large wood as it is transported downstream (Millington and Sear, 2007), causing accumulations that dam the river and produce hydraulic steps in the long profile (Curran and Wohl, 2003). The increased flow

\footnotetext{
* Corresponding author. Tel.: +44 2380592215; fax: +44 2380593295 E-mail address: D.Sear@soton.ac.uk (D.A. Sear).
}

resistance and reduced channel capacity caused by logjams can lead to a significant increase in the frequency and duration of overbank flows (Gregory et al., 1985; Brown, 1997; Jeffries et al., 2003) and an increase in the residence times of organic and inorganic material in the channel (e.g. Nakamura and Swanson, 1994; Smith et al., 1993; Keller et al., 1995; Millington and Sear, 2007).

Once on the floodplain, overbank flow is concentrated by topography and by obstacles created by vegetation and dead wood, leading to complex floodplain scour and deposition. This has been shown to result in the creation of diverse floodplain geomorphology (Brown, 1997; Piégay, 1997; Jeffries et al., 2003). This, together with long residence times of organic and inorganic material, forms a mosaic of physical habitats supporting diverse vegetation and ecology (e.g. Amoros and Petts, 1993; Naiman et al., 1993; Marston et al., 1995; Ward et al., 2001), which in turn promotes geomorphological diversity. A number of studies have described channel avulsions triggered by wood accumulations in a variety of environments (Harwood and Brown, 1993; McKenny et al., 1995; Piégay and Marston, 1998; Piégay et al., 1998; Collins and Montgomery, 2002; Abbe and Montgomery, 2003; Jeffries et al., 2003). In forested regions, 
the formation of stable logjams promotes the evolution of an anastomosing channel morphology (Harwood and Brown, 1993; Collins and Montgomery, 2002; Montgomery et al., 2003; O'Connor et al., 2003), though these are characterized by active bedload transport and unconfined channels. Finally, local coarse sediment deposition upstream of logjams can form alluvial surfaces (Montgomery and Abbe, 2006) several meters higher than the active floodplain and hence contribute directly to floodplain formation.

The aim of the paper is to define the processes and resulting morphology associated with the role of logjams in the formation and maintenance of floodplain surfaces. To do this we draw on a specific case study, before extending the discussion using published examples from other river types to show that although the processes of interaction differ, the resulting dynamic floodplain patchwork is a common feature of rivers with logjams. In addition, we contend that the presence of logjams is an important factor in the evolution and maintenance of multiple channel patterns in both montane and lowland river environments. These observations have important implications for the definition of reference targets for river restoration.

\section{Regional and site setting}

We use a case study site to explore in some detail the processes associated with logjam forced channel:floodplain interaction. The choice of case study is designed to contrast existing studies of logjam mediated channel:floodplain interaction (e.g. Brummer et al., 2006; Montgomery and Abbe, 2006), and thus raise the wider question of the role of logjams in the evolution of floodplain:channel systems.

The case study sites lie in two third-order tributaries of the Lymington River, located in the New Forest, southern England (Fig. 1; Table 1). The sites are characterized by Tertiary marine lithology (clays) and a flashy hydrological regime (Piégay and Gurnell, 1997; Gurnell and Sweet, 1998). The floodplain sediment sequences range from $<0.5 \mathrm{~m}$ in the headwaters up to $1.2 \mathrm{~m}$ in the lower catchment. Thin humous rich forest soils overlie silty-sand and silty-clay alluvium. The alluvium overlies fluvial gravels which in turn overlie weathered clay parent material. The shallow soils restrict the rooting depths of trees, forcing root networks to spread horizontally. Shallow rooting on floodplains, makes the trees sensitive to wind-throw (Brown, 1997); the major process of wood recruitment in the study rivers.

Peterken et al. (1996) defined the woodland adjacent to the study rivers as National Vegetation Classification (NVC) type W7b Alnus glutinosa-Fraxinus excelsior-Lysimachia nemorum community (Rodwell, 1991). This type of woodland fundamentally depends on hydrological processes and is normally found on valley slopes at mineral-rich flushes such as springs or seepage lines, but it is also supported by the fluvial and hydrological processes that occur on the floodplains of the Highland

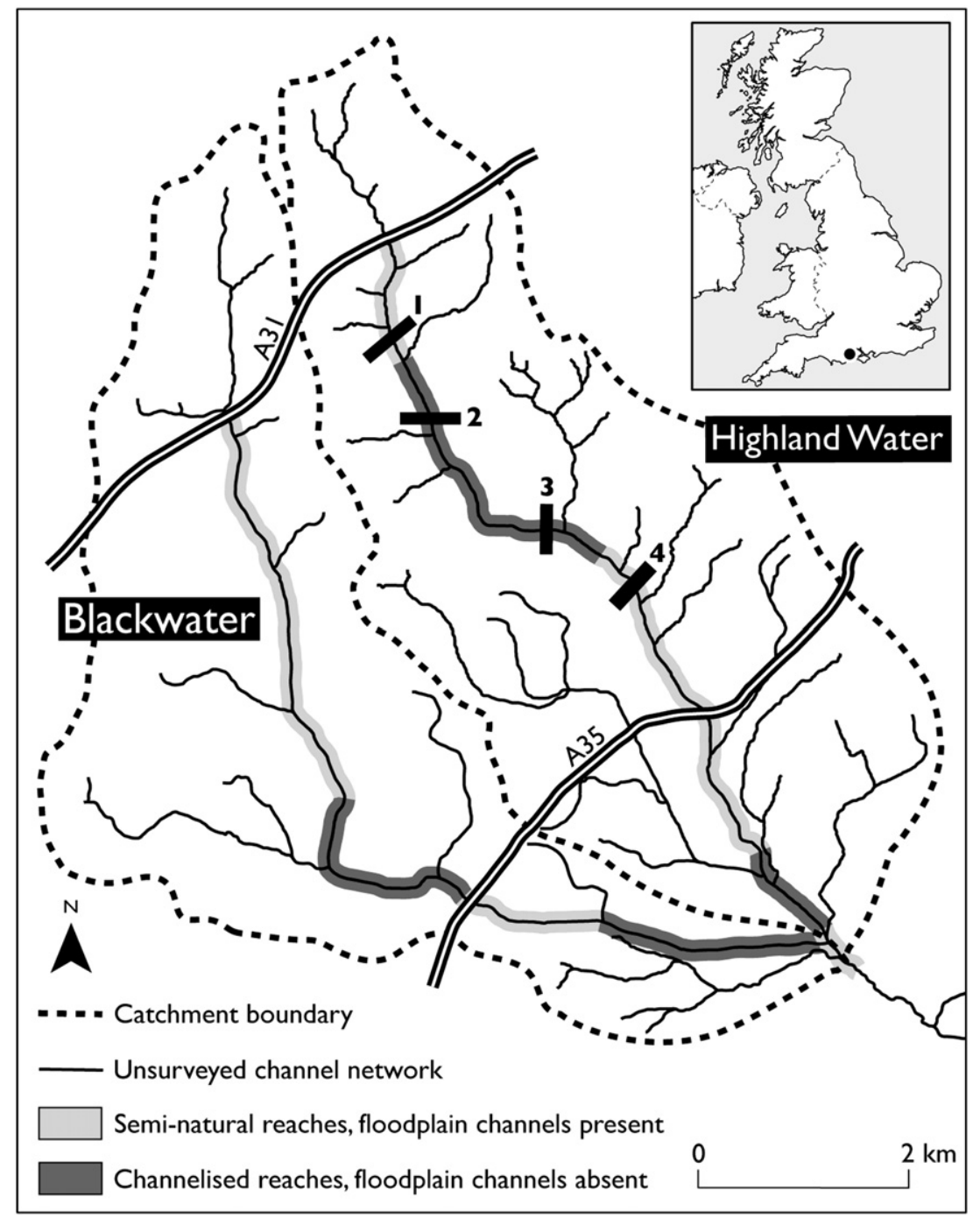

Fig. 1. Study site showing location of specific study reaches (1-4). The River network has been classified into reaches according to whether or not floodplain channels were present. Those where floodplain channels were absent were also channelised resulting in reduced channel:floodplain connectivity. 
Table 1

Summary details for the Lymington River headwater study catchments Highland Water and Blackwater.

\begin{tabular}{lll}
\hline Characteristic & Highland Water & Blackwater \\
\hline Catchment area $\left(\mathrm{km}^{2}\right)$ & 25.23 & 25.52 \\
Total stream length $(\mathrm{km})$ & 44.33 & 30.17 \\
Drainage density $\left(\mathrm{km} / \mathrm{km}^{2}\right)$ & 1.76 & 1.18 \\
Length of main stream $(\mathrm{km})$ & 10.59 & 12.11 \\
Relief (max to min) & $97(105$ to 15$)$ & $80(95$ to 15$)$ \\
Slope $(\mathrm{m} / \mathrm{m})$ & 0.0092 & 0.0066 \\
Solid geology & Barton clay and sand & Barton clay and sand \\
Drift geology & Alluvial silt and gravels & Alluvial silt and gravels \\
Valley soils & Wet alluvial brown earth & Wet alluvial brown earth \\
Land cover & Forest/heathland & Forest/heathland \\
Land management & Forestry/commoning & Forestry/commoning \\
\hline
\end{tabular}

Water and Blackwater. The physical habitat of type W7b AlnusFraxinus-Lysimachia woodland is controlled by the relationship between weathered parent rock (regolith) and hydrology. Frequent overbank flow physically redistributes allocthonous material - such as wood and leaves - across the floodplain, and as much as $13 \%$ of sediment deposited during overbank flow is organic (Jeffries et al., 2003).

Since the 1840s, a large proportion of the streams in the forest (particularly those flowing through the inclosures) have been periodically straightened and dredged in order to improve drainage (Tuckfield, 1980; Tubbs, 2001) and allow conifers to be planted (Gurnell and Sweet, 1998). Straightening and dredging has resulted in habitat fragmentation, reduced ecological and geomorphological diversity in the streams, and has triggered further downcutting of bed levels and headward erosion of streams into the mires (Tubbs, 2001; Sear et al., 2006). The presence of both channelized and seminatural river reaches created an opportunity to distinguish the processes and features that are specific to coupled channel:floodplains with logjams.

\section{Methods}

A suite of field-based methods and techniques were used in order to characterize the nature of the channel:floodplain interaction and to quantify the processes of erosion and deposition on the floodplain. At the catchment scale, walk-through surveys were undertaken to characterize and document the channel and floodplain features observed in $100 \mathrm{~m}$ reaches along the study streams. Transects were walked at $100 \mathrm{~m}$ intervals across the floodplain and the frequency of features recorded on a standard proforma derived from a pilot study. In addition, LiDAR (Light Detection And Ranging) data were used to map the positions of the main and floodplain channels along both study streams. These were augmented by cross-sections surveyed at $100 \mathrm{~m}$ intervals along the channels and that extended across the floodplain. Field mapping of specific reaches was undertaken to ground truth the LiDAR mapping, and to provide additional detail of the floodplain morphology. This included long-profile surveys of floodplain channels.

Gurnell and Sweet (1998) reported the dynamics of wood and pool habitats within a $5 \mathrm{~km}$ reach of the Highland Water study stream. Their study was based on field mapping the features along the main channel network. This study adopts a similar approach in order to quantify the more recent logjam dynamics within both study streams. The locations of logjam centre points were mapped in the field using a hand-held GPS linked via wireless connection to ARCPAD GIS mounted on a PDA palm top computer. This enabled direct mapping onto digital base maps and provided two modes of position verification - first the GPS (accurate to within $+/-10 \mathrm{~m}$ on average under partial tree cover) and secondly the base map channel morphology and geographic information layers on the PDA. Assessment of the positional accuracy was checked against known immobile features such as bridges, fords and boundary locations. Fifty measurements were made throughout the study reaches. The resulting positional accuracy was precise to within $+/-1.5 \mathrm{~m}(\sigma=1.04 \mathrm{~m})$ of a centre point. All subsequent analysis has therefore been adjusted to account for the positional error with change in the location of features only being accepted if they are larger than $2 \mathrm{~m}$ in either up or downstream direction. Lateral channel change is limited in the study streams (Gregory, 1992; Davis and Gregory, 1994; Jeffries, 2002) except where channelization or restoration has changed the position of the main river. The surveys were undertaken during low flows in October 2002, repeated in June 2006 and again in October 2007. The main trunk streams of both the Highland Water and Blackwater were surveyed from the confluence of the two rivers up to where a major road crosses at the A31 (see Fig. 1).

The flow resistance of reaches with single logjams was measured over a distance 10 channel widths (typically $30 \mathrm{~m}$ ) with the logjam at the centre of the reach. Discharge, water surface slope and crosssection area were measured across a range of flows including floodplain inundation. Over 30 measurements were made for each logjam type. Roughness partitioning was applied using the grain resistance equation of Hey (1979); bend resistance was approximated using head loss coefficients, and a methodology suggested by Gippel (1995) was implemented in order to predict the resistance offered by the LWD within the reach. The Darcy-Weisbach friction factor $(f)$ was used as it is dimensionally correct and has a sound physical basis when compared to other commonly used roughness coefficients (Hey, 1979), however, these values were converted into Manning's roughness $(n)$ equivalent, since this is more widely used.

Logjams were classified according to the system devised by Gregory et al. (1985) in which 'Active dams' refer to logjams that are hydraulically effective, physically block the channel and have average measured Manning's roughness values $n$ of 1.420 (range $0.475-2.329$ ). Active dams pond water behind them during low to medium flows and create a step in the water surface profile at low flows, elevating the water surface by up to $89 \%$ of bank height. During higher discharges, Jeffries et al. (2003) and Sear et al. (2006) report increases in overbank flood duration upstream of Active dams of between 200 and 500\% ( 5 days) relative to reaches without dams (1 day); and an increase in overbank flood frequency of $300 \%$. 'Complete dams' span the channel but do not influence low flow hydraulics due to under-scour, $(n=0.25$; range $0.159-0.505)$ whilst 'Partial dams' occupy up to $75 \%$ of the channel $(n=0.32$; range $0.141-$ 0.609). 'High water dams' refer to trees that have fallen across the channel but are suspended on the bank tops. These do not affect flood flows in all but bankfull events, when they may act to locally deflect water out onto the floodplain.

To quantify the influence of logjams on rates of overbank sedimentation and erosion, a set of four sites were selected that represented a range of process domains. Site 1 is a headwater seminatural site with a central Complete logjam (stream order 3); site 2 is a restored fourth order channel with an Active logjam. Site 3 is on a channelized reach within a coniferous plantation. Site 4 is a lower order (Strahler stream order 4) semi-natural reach with a central Active logjam. At each site, two transects of $0.25 \mathrm{~m}^{2}$ Astroturf ${ }^{\mathrm{TM}}$ mats were set up across the floodplain to measure sedimentation rates (Nicholas and Walling, 1995; Steiger et al., 2001). Mats were spaced across the floodplain at specific points designed to quantify processes associated with specific features of the floodplain geomorphology (e.g. in a floodplain channel, on a floodplain surface). These were sampled after every flood event during the period 2004-2006. The mats were placed in polythene bags and returned to the lab for particle size analysis and loss on ignition for organic content. New mats were replaced at each sample site.

A series of techniques were also used to measure the rates of incision on the floodplain surface. These were: 1 ) a network of plastic erosion pin transects (Lawler et al., 1997) located upstream and 
downstream of Active logjams at the four sites that sampled floodplain channels and adjacent floodplain surfaces; 2) topographic measurements of floodplain channel incision below the floodplain surface where the date of incision was known from root analysis (see below) and; 3) measurement of new floodplain channel incision where the date of incision was known. A total of 296 erosion rate measurements were collected using these techniques. For the erosion pins, sampling frequency was initially after each flood event, but was reduced to after each flood season. Exposure lengths were converted into rates based on the measured duration of inundation during floods. The latter information was captured by calibrated pressure transducers located in the study reaches (Sear et al., 2006; Millington, 2007).

The longevity of logjams and the age of floodplain channels were required in order to estimate large wood jam dynamics and to quantify the rates of floodplain erosion. Large wood jams were dated in two ways; first by dating tilt sprouts on keystone logs, using growth ring counts (Hupp, 1990) and secondly, by reference to the position of the dams on surveys dating back to 1982 for the Highland Water, and 1991 for the Blackwater. Ages were established for dams that existed in the same location (see accuracy criteria above) on subsequent surveys (1982, 1983, 1990, 1996, 2000, 2002, 2004, and 2007) up to a maximum date of 26 years.

The age of floodplain channel formation was determined by dating exposed roots. Dendro-geomorphological analysis of tree stems and roots has been widely used to date both erosion and aggradation (e.g. Strunk, 1997; Vandekerckhove et al., 2001; Bodoque et al., 2005; Friedman et al., 2005; Malik, 2006; Mizugakia et al., 2006; Gärtner, 2007). When roots are exposed, they start to put on growth rings. Development of floodplain channels exposes tree roots. Two samples of root from each floodplain channel were analyzed; one from the exposed root and one from the same root but where it was still buried. The difference between the two identified the growth post-exposure (further details are available from Millington, 2007). Three roots per floodplain channel were sampled. However, since the study catchments are located within a designated Site of Special Scientific Interest and Ancient Woodland, the number of sites sampled had to be limited to six.

\section{Results}

\subsection{Floodplain features}

The range of features associated with overbank flooding within a forested floodplain is differentiated between reaches that have been channelized and those that are still connected to the floodplain (Fig. 2). Overbank flood processes create a suite of depositional features, including sand and silt splays on the floodplain surface within meander bends, and sediment shadows downstream of obstacles (trees, logs, and shrubs). These depositional features are also found within and adjacent to the network of floodplain channels that dissect the floodplain surface. Sediment shadows are reported from a range of environments and result from the rapid drop in velocity and resulting low pressure zone found downstream of obstacles (Brayshaw et al., 1983; Richards and Clifford, 1991). On the floodplain sediment shadows reached widths of up to $1 \mathrm{~m}$, and lengths of $2.5 \mathrm{~m}$, with local elevations up to $0.25 \mathrm{~m}$ (average $0.12 \mathrm{~m}$ ) above the surrounding floodplain surface. Sediment shadow width is strongly correlated with obstacle width which is frequently a living tree, whilst length and height are less clearly associated with obstacle dimensions. Sediment shadows are aligned in the direction of flow, and are therefore useful indicators of floodplain flow direction.

Other depositional floodplain features include organic matter accumulations that are composed of material rafted on to the floodplain from the channel and/or floodplain material which has been re-distributed by overbank flows. These deposits are composed

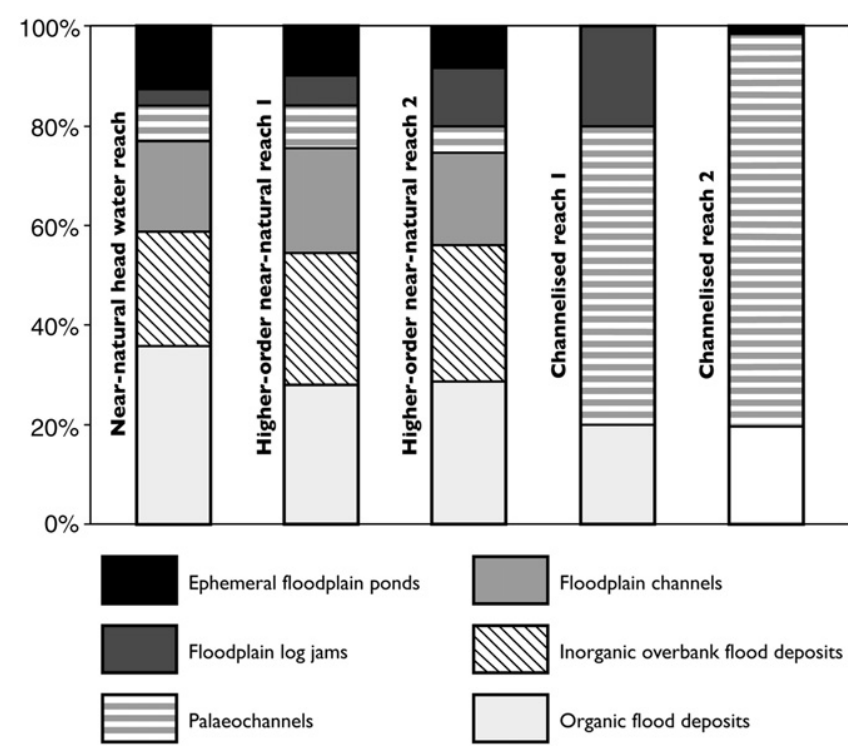

Fig. 2. Frequency of floodplain features on semi-natural and channelised reaches within the study streams. Channelised reaches exhibit few active erosional or depositional features on the floodplain commensurate with loss of channel:floodplain connectivity. In contrast semi-natural reaches show very similar suites of floodplain features with the formation of floodplain pond habitats associated with the evolution of floodplain channels.

of a complex matrix of large to fine particulate organic matter, fine sand, silt and clay. They also contain seeds and are important germination sites for trees and shrubs. Rafts of organic detritus arrange themselves into complex accumulations that are mobilized only when another overbank flood of similar or greater magnitude occurs (Piégay, 1997). Hence the longevity of these features is a function of flood hydrology, local factors that influence overbank flooding (see Jeffries et al., 2003), and the decay rate of the organic material. In some cases these rafts form floodplain jams with large wood trapped against standing trees which influence the direction of subsequent overbank flows. These jams may also act as deposition foci for more organic matter, prompting further growth.

Alongside the depositional features, the floodplain surface exhibits erosional features including areas of scour exposing a meshwork of tree roots, and networks of ephemeral channels. These erosional floodplain features are associated with advected flow on the floodplain during overbank floods. Deeper scoured reaches of floodplain channels create temporary floodplain pools that contain water in all but the driest months. In a few cases, these channels can become permanent flowing sections of the river network (Millington, 2007).

The abandoned course of the former channel dominates the floodplain features in channelized reaches. This is unsurprising since the old channels in this river have simply been left abandoned on the floodplain under the coniferous plantations. Such channels are less frequent in the semi-natural reaches which is in accordance with the limited lateral mobility reported for these streams (Gregory, 1992; Davis and Gregory, 1994; Jeffries, 2002).

The surface of the forested floodplain is complex. A vegetated surface is dissected by incised channels and by a network of tree roots and large wood (trees and fallen wood). Fig. 3a and b shows crosssections through a floodplain surface (see Fig. 1 for location). Topographic high points are strongly associated with the presence of trees and root systems. Close to the main channels, where sediment deposition rates are relatively high (Jeffries et al., 2003), trees and associated root systems form low pressure areas in which fine suspended sediment and organic matter and seeds accumulate. Hence the presence of trees leads to local aggradation, the build up of the floodplain surface, and its extension in the direction of overbank flow. 

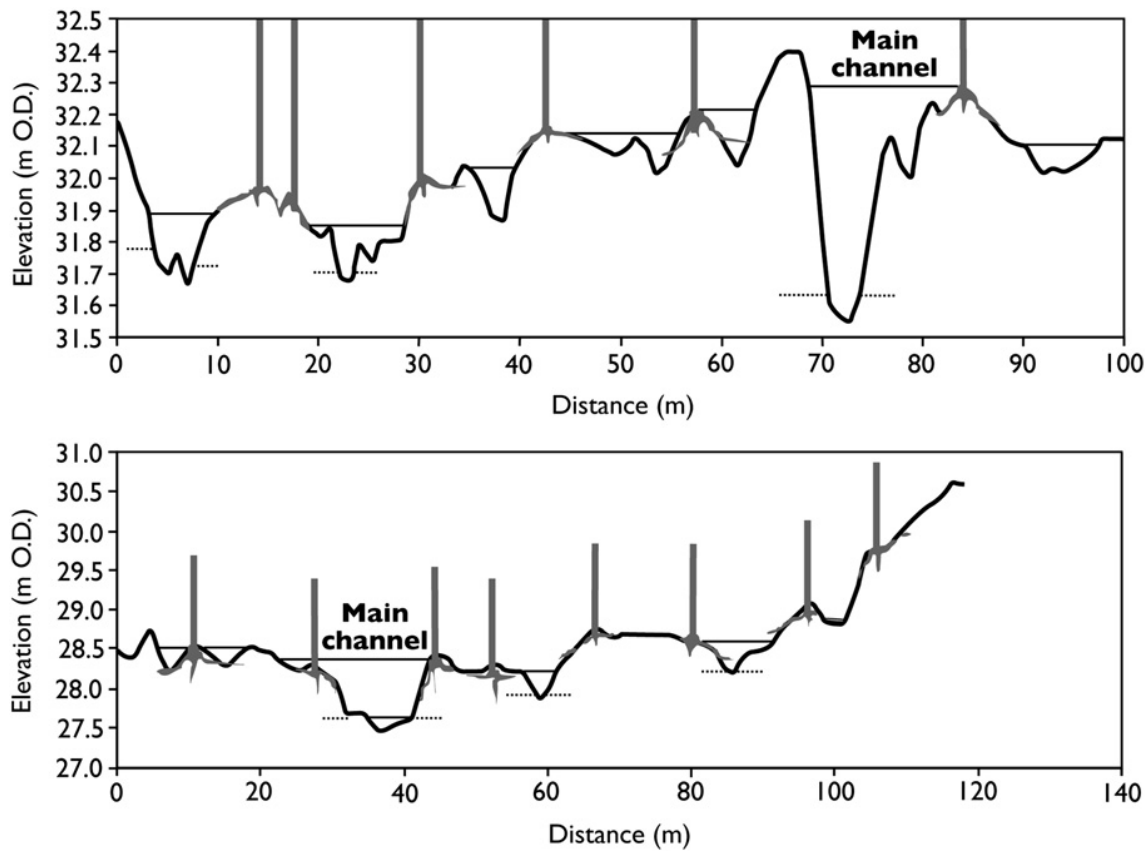

Fig. 3. Cross-sections through site 2 and site 4 , showing the different vegetated surfaces and floodplain channels that characterize the forested floodplains within the study sites. The position of trees and root systems influence the development of topography. Variability in the elevation of floodplain surfaces ranges from 0.019 to 0.310 . In contrast the elevation differences due to floodplain channel formation range from 0.012 to $0.690 \mathrm{~m}$.

In contrast, the floodplain channels form topographic low points in the floodplain, often with localized areas of scour downstream of larger roots (Fig. 4).

\subsection{Floodplain channel pattern and morphology}

The network of the main channel and floodplain channels create a complex branching pattern (Fig. 5) that dissects the floodplain throughout the study streams. The contribution of floodplain channels to the total length of channeled flows in the floodplain varies downstream in no predictable pattern, but tends to be lower in the headwaters compared to higher order reaches. The resulting channel pattern is best described as branching, with intervening vegetated floodplain islands, although the main river planform is an incised, single meandering channel. Individual floodplain channels are sinuous with some bends; meandering is generally not present, and lateral erosion processes are only evident in isolated deeper sections. Lateral migration is, like the main channel, constrained by cohesive floodplain soils and tree roots (Davis and Gregory, 1994; Jeffries et al., 2003).

Individual floodplain channels typically exit from the main channel at a meander bend, and most frequently at the downstream end of a meander bend where this cuts normal to the floodplain axis. The floodplain channels may be single and re-enter the main river across the neck of the meander (14\% of all floodplain channels in the Blackwater (BW) and 26\% in the Highland Water (HW)) or may
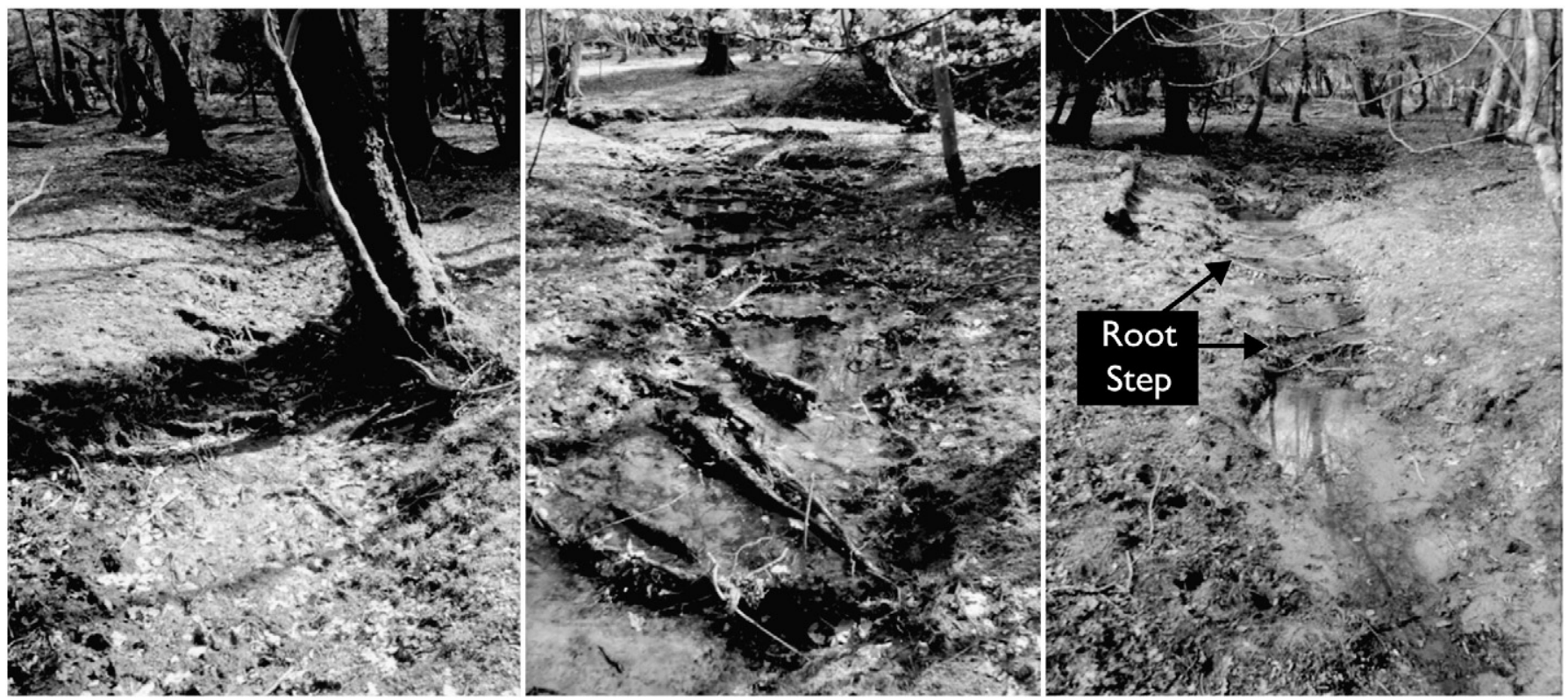

Fig. 4. Floodplain channels showing the network of exposed roots in the long profile that form locally intense regions of scour, but which also prevents head wards erosion until the roots are undermined. 


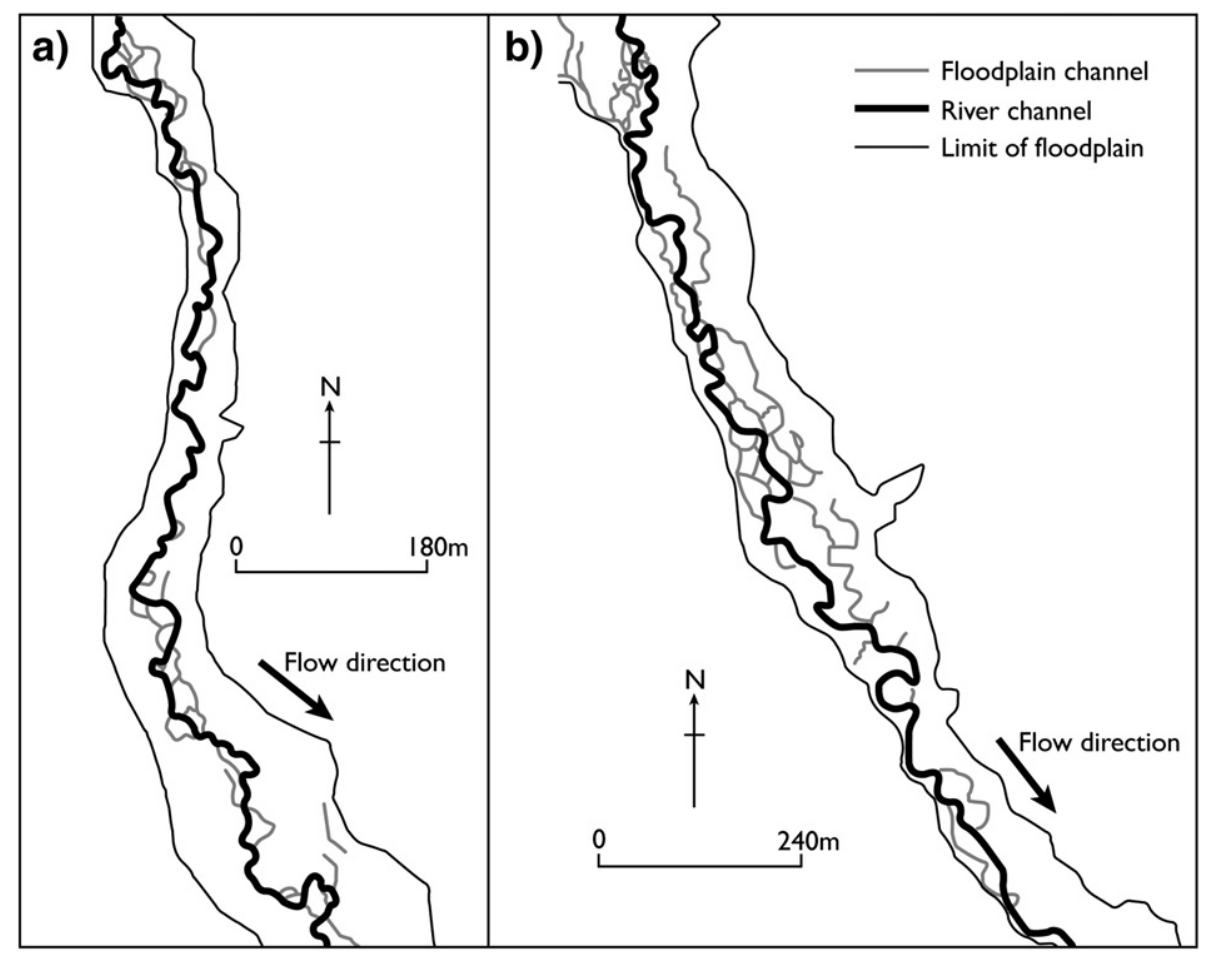

Fig. 5. Multiple channel pattern of floodplain channels and main meandering river from semi-natural sites on the Highland Water and Backwater.

bifurcate and re-enter in more than one location across the neck of a meander $(17 \% \mathrm{BW}, 18 \% \mathrm{HW})$. These are similar to other meander neck cutoff channels (Howard, 1996; Gay et al., 1998; Thompson, 2003). The dominant type of floodplain channel pattern exits the main river at a meander bend and circumvents several bends before re-entering the channel. These can be single channels (32\% BW, 26\% HW) or multiple branching channels (36\% BW, 31\% HW). Fig. 6 shows a provisional typology of floodplain channels based on the study sites. Type 1 is the single channel meander bend cut off; Type 2 is similar but has multiple branching channels. Type 3 contains either single or multiple branching channels that may or may not exit at a meander bend.
The long profiles of floodplain surface and floodplain channels are shown in Fig. 7. Topographic high points in the floodplain channels are associated with localized increases in root density which in turn relates to the proximity to trees. Once a larger root is exposed (Fig. 4), it behaves like a grade control, locally increasing the energy grade line over the step, resulting in increased scour and in some cases the development of plunge pools. The long profiles are characterized by a series of disconnected scour pools, areas of surface scour, and, at the downstream re-entry point, zones of head cutting. The head cutting process is at a maximum during the rising and falling limb of the flood before the water elevation in the main channel drowns out the lower floodplain channel (Fig. 7), and in locations where hydraulically active

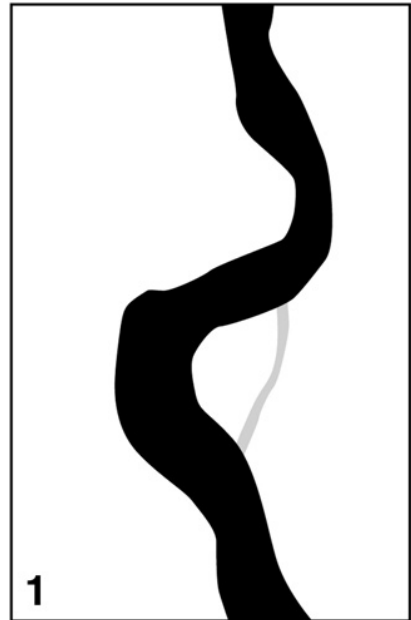

急Log jam

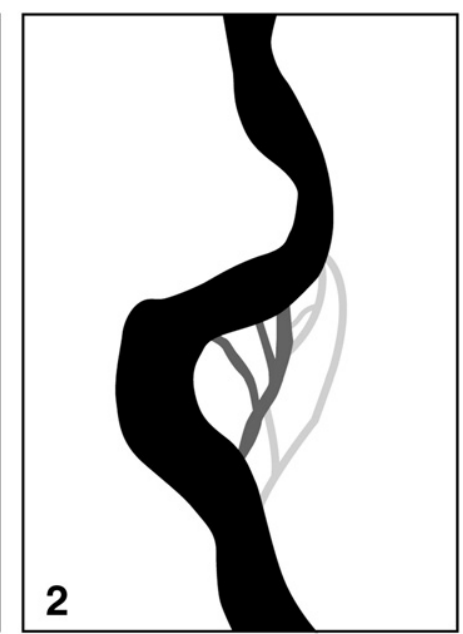

Main channel

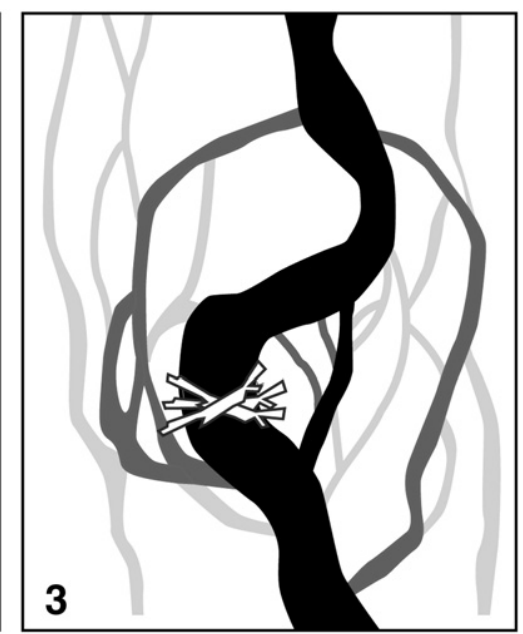

Shallow floodplain channel $(<0.10 \mathrm{~m})$

Fig. 6. A typology of floodplain channels. Type 1 is analogous with a meander neck cutoff. Type 2 is a more complex neck cutoff with multiple channels. Type 3 is the most complex and includes neck cutoff and avulsion driven channels that from in the absence of meanders. 

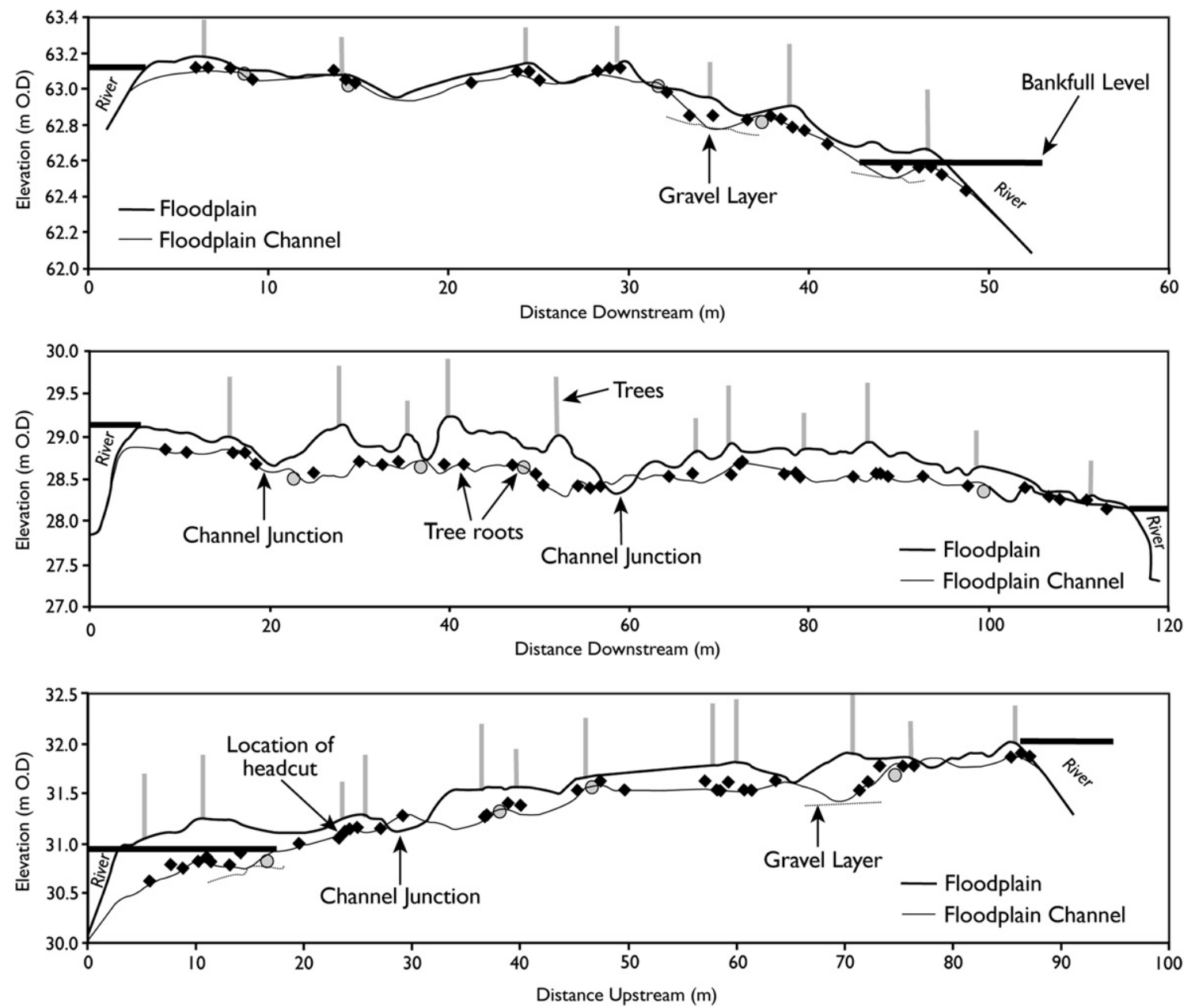

Fig. 7. Long profiles of floodplain channels in relation to the floodplain surface and bank full elevations. Head cutting at the point of re-entry into the main channel is shown by rapidly steepening gradients. The role of transverse tree roots in preventing incision and in promoting downstream scour is clearly evident.

wood dams force water into a floodplain channel during lower magnitude floods.

The capacity of floodplain channels relative to the main channel defines the proportion of channeled flow within the floodplain crosssection. Although individual floodplain channels can attain widths that are comparable to the main channel, their depths are typically much shallower $(0.20 \mathrm{~m})$ than main channels $(0.87 \mathrm{~m})$. The shallow depths reduce total floodplain cross-section capacity (on average $164 \%$ smaller than main channel capacity) even in the presence of multiple channels. However, in two cases within the study reaches floodplain channels have formed perennial secondary channels.

\subsection{Logjams and floodplain channels}

The location of floodplain channels and depositional features are clearly associated with reaches with floodplain connectivity. However, not all reaches have floodplain channel development or ephemeral pools. Fig. 8 shows the location of logjams in relation to the floodplain channel networks. Large wood dams increase flow resistance (Sear et al., 2006), physically block the channel and increase water surface elevation upstream of the dams (Jeffries et al., 2003). However, unlike more active bedload transporting rivers, stream bed aggradation upstream of active logjams is not widespread and does not force overbank flooding and lateral channel migration (Brummer et al., 2006). Rather it is the water surface elevation changes resulting from the physical blocking and flow resistance created by a logjam that elevates the upstream water surface in the study streams.
We hypothesized that the important factors for initiating floodplain erosion and deposition processes would include the presence of Active logjams in shallow channel cross-sections (those with low banks) and secondly, highly sinuous channel planforms that result in super-elevation of the water surface and advection of flows onto the floodplain at the meander bend apex (Bathurst et al., 1977). To test this hypothesis, data on channel sinuosity, bank height and Active logjams, were collected from locations with and without floodplain channels. Local height of the banks relative to bed level, was measured on either side of any existing floodplain channel exit point, and is thus assumed to be independent of the presence of a floodplain channel. Student's $t$-tests were run $(p=0.05)$ in order to test if the observed differences in the characteristics between reaches where floodplain channels were present and where they were absent were significantly different. For those reaches with floodplain channels, channel sinuosity was significantly higher, bank height channel was significantly lower, and there were significantly more Active logjams/100 m. Furthermore, the more complex networks of floodplain channels were always associated with hydraulically active wood jams, whereas single-channel meander neck cut-offs were most often associated with tight bends with low bank points at the downstream end of the bend where it cut back across the floodplain.

\subsection{Logjam dynamics and floodplain channel formation}

Wood structures in the study streams have been shown to influence the frequency and duration of overbank flooding, floodplain 


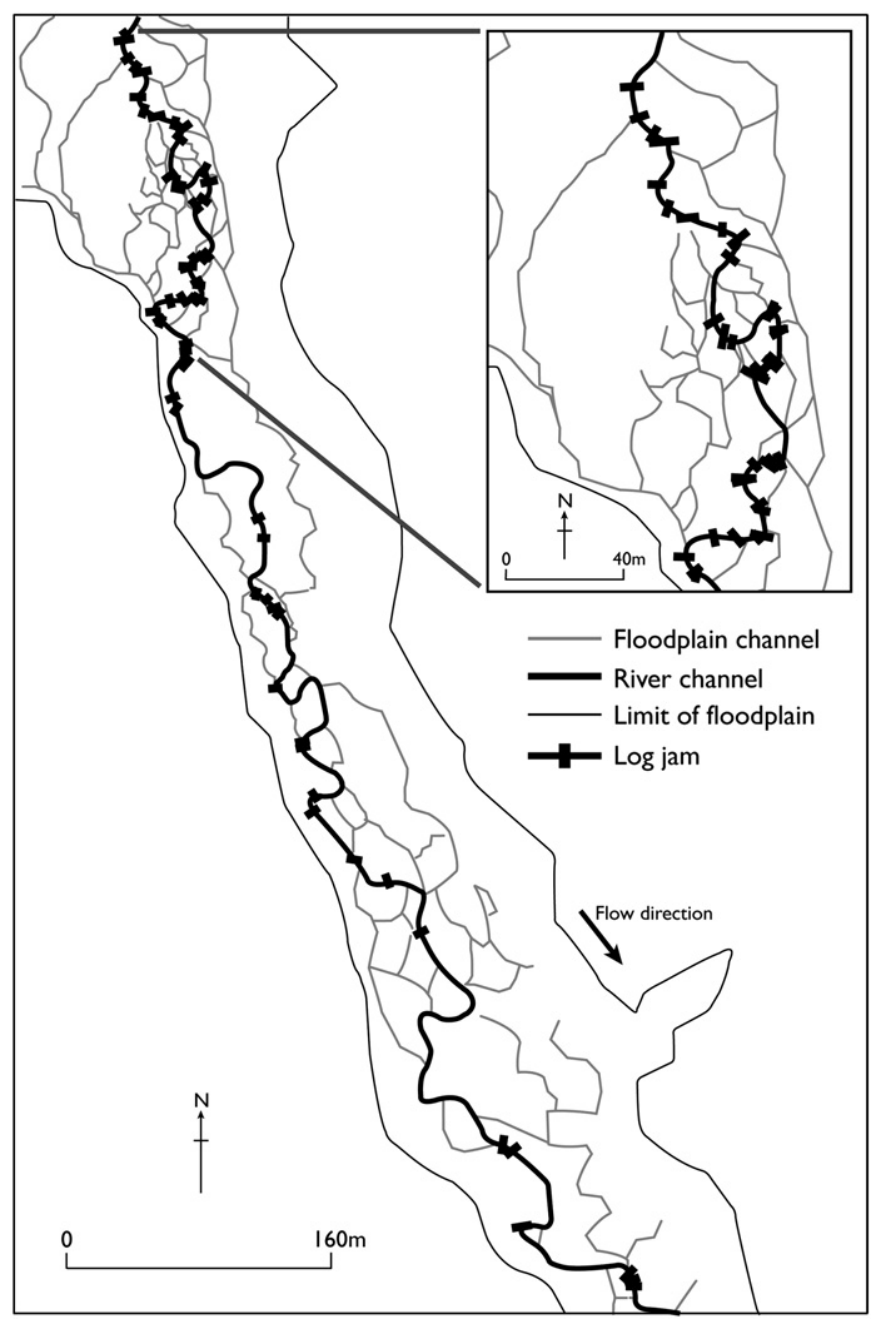

Fig. 8. Location of logjams in relation to the floodplain channel network. Although not all floodplain channels are associated with logjams, the total number of logjams shown is considered to be lower than historically unmanaged levels.

deposition and wood retention (Gregory et al., 1985; Jeffries et al., 2003; Millington and Sear, 2007). Furthermore, in semi-natural reaches of the study streams, Millington and Sear (2007) showed that up to $11 \%$ of small wood was transferred onto the floodplain, leading to wood accumulations such as those observed in the feature surveys. It was hypothesized that the type and location of logjams would be an important control on the development of the floodplain morphology, and therefore the dynamics of logjams would be an important measure in relation to understanding floodplain evolution within the study streams. Two measures of logjam dynamics were quantified; changes in logjam type which relates to flow resistance (essentially changes in drag and porosity over time, Manners and Doyle (2008)), and the location of logjams in the river.

The four main logjam types within the study streams show variability in their frequency over time (Fig. 9a). The changes result from natural recruitment processes together with management (removal) in 1990-96. The distribution of dam types has changed from a dominance of partial dams and few high water dam types prior to 2002 , to one in which fallen trees (high water dams) are growing in number in the absence of management, and partial and complete dams are increasing. Active dam types have reduced in frequency since 2002. Active logjams typically change into complete jam types by scouring under or to the side, resulting in an increase in logjam porosity and a decrease in flow resistance. In $82 \%$ of the cases the change in Active logjams was to Complete logjam types in the period
1982-2008, with the remaining $18 \%$ to Partial logjams. In contrast, $80 \%$ of Complete logjams remained the same or changed to Partial logjams. In addition to the processes of wood recruitment and management, logjam types can change over the longer term through the decay and collapse of large wood structures. This process results in a change in high water logjams into Partial or Complete structures through collapse into the channel and the subsequent accumulation of smaller mobile wood against the keystone log (Millington and Sear, 2007).

Within temperate deciduous forests such as the study streams, the dam dynamics are also seasonal, with changes in type resulting from two main processes; seasonal accumulations of leaf packs on dams following leaf fall in the autumn, and the action of flood events. The latter mobilizes wood within the channel and dam structures, resulting in changes from partial to complete/active, and from active/complete to partial. The leaf fall in autumn decreases the porosity of existing dam structures and increases flow resistance leading to changes from complete to active dam types. However, leaf packs rapidly breakdown and mobilize, so this seasonal affect is most marked in October to December, coinciding with the onset of the winter flood season.

A key aspect of logjam dynamics is the mobility of the jams themselves since the location of the jam will influence channel forming processes (e.g. pool creation Montgomery et al., 1995; Montgomery and Buffington, 1997) and the point of connectivity with the floodplain (Jeffries et al., 2003). Gregory et al (1993) calculated that the study streams trap $65 \%$ of all wood recruited to the channel and exports only 35\% to downstream reaches. Thus the mobility of logjams was initially thought to be minor. In the event, the distance logjams move is typically short, with mean logjam movement between years ranging from 6.9 to $8.8 \mathrm{~m}$. Fig. 9b documents logjam positions over the past 23 years within the Highland Water semi-natural study reaches. Loss and gain of logjams from a site dominate, with logjam movement accounting for between 5 and 23\% of dynamics in semi-natural reaches. Persistence at a site typically accounts for $14 \%$ of logjams, falling to $10 \%$ in years with wood management. In total only $14 \%$ of logjams remain in position between surveys, and of these only $4 \%$ persisted across all 23 years; $86 \%$ of logjams changed location between surveys. In addition, of those logjams that persisted at a site, $69 \%$ changed logjam type between surveys. Only 3\% of logjams retained type and position across all 23 years of survey in semi-natural reaches, though where they retained position they tended to retain type. In these cases, persistence resulted from the presence of either a living or particularly large (diameter $>0.8<1.5 \mathrm{~m}$ ) keystone log that was immobile during floods and presumably too large for debris management.

\subsection{Rates of floodplain channel formation}

In order to identify if floodplain channel initiation coincided with logjam establishment, the highest exposed tree roots in floodplain channels were analyzed to establish when they were first exposed, and therefore a minimum period since the floodplain channels first started to form (assuming the surface was eroded first to expose the root).

Table 2 collates the results from logjam ageing and from dating exposed roots in floodplain channels. Since tilt sprouts grow after a tree becomes horizontal but remains alive - they therefore give a minimum age for a logjam, but not necessarily when it started to be hydraulically effective. In addition, previous logjam surveys were used to identify date bands for when a given logjam had been hydraulically effective.

Table 2 indicates that, although floodplain channels of Types 1 and 2 formed in the absence of logjams, they were more frequently associated with logjams (of any type). The development of Type 1 or Type 2 floodplain channels does not appear to be related to the type or 

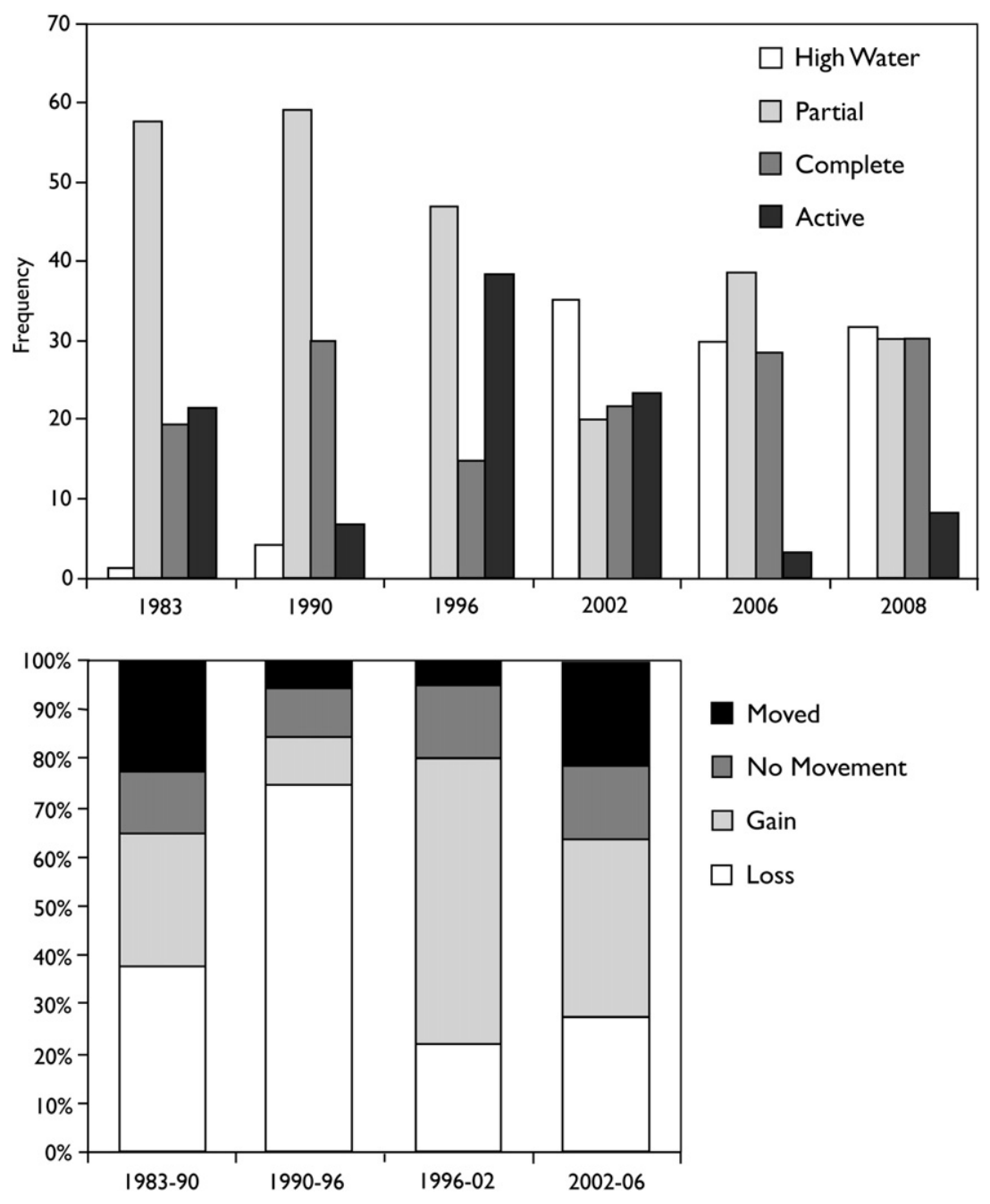

Fig. 9. a: Wood dam dynamics in semi-natural reaches of the Highland Water study stream. Changes in the frequency of wood dam types for semi-natural reaches within the Highland Water study stream based on field surveys. Flow resistance increases from high water-active dam types. b: Wood dam dynamics illustrating the dominance of gain and loss of dams from a site compared to those that move or remain in-situ. Loss between 1990 and 1996 results from management activity in the streams.

the longevity of logjams. However, Type 3 floodplain channels occurred in association with hydraulically effective logjams, and developed relatively rapidly ( $<15$ years). The length of time since root exposure roughly corresponded with logjam age bands, and roots that had been exposed for longer tended to be associated with Type 3 floodplain channels. More recently exposed roots were associated with Types 1 and 2 (although note the large variability in the period of root exposure from different root samples within the same floodplain channel, Table 2). From the data it is not possible to determine how long a logjam needs to remain in the same location in order for floodplain channels to develop, however, the data do indicate that Type 3 floodplain channels only developed where hydraulically effective logjams had been present in the main channel for more than 6 years.

In addition to the dating, a series of floodplain erosion measurements were made to quantify the rates of incision in floodplain channels. Incision rates were calculated on the basis of the duration of overbank flooding. The modal rate of incision in floodplain channels based on all three sources of evidence is $0.036 \mathrm{~m} \mathrm{yr}^{-1}$ with a mean value of $0.040 \mathrm{~m} \mathrm{yr}^{-1}$. The value for erosion pin and for recent floodplain channel formation is similar at $0.025 \mathrm{~m} \mathrm{yr}^{-1}$ and $0.024 \mathrm{~m} \mathrm{yr}^{-1}$ respectively. These values mask a variance about the mean of $0.011 \mathrm{~m} \mathrm{yr}^{-1}$. Rates of incision tend to be largest downstream of large channel-spanning roots, where plunge-pool scour holes form in the bed of the floodplain channels, or where head cutting processes operate at re-entry points into the main channel. In these locations rates of incision can be an order of magnitude higher $\left(0.204 \mathrm{~m} \mathrm{yr}^{-1}\right)$. Extrapolating these erosion rates over the typical lifespan of an active wood dam of 6 years, results in a maximum modal depth of incision of between 0.150 and $0.210 \mathrm{~m}$, which corresponds to the modal depth of floodplain channels within the study reaches.

Incision rates in floodplain channels are only $15 \%$ faster than those on adjacent floodplain surfaces over the two flood seasons for which measurements were available. This appears to result from the differential operation of erosion and deposition, which over time creates a net incision rate in the floodplain channel. Floodplain channel infilling was also observed throughout the two study catchments. The main processes involved being deposition within former re-entry points as a result of subsequent ponding upstream of a logjam. In these locations accumulation rates can be rapid (up to $0.3 \mathrm{~m}$ in one flood season) and equivalent to the rates of incision at reentry points.

\subsection{The role of logjams and floodplain channels in overbank deposition}

Once on the floodplain, the water, sediment and organic matter interact with the existing network of trees, shrubs, topography and floodplain sediments, to create a complex erosional and deposition environment (Piégay and Gurnell, 1997; Jeffries et al., 2003). This is 
Table 2

Chronology of logjam and floodplain channels derived from dendrochronology and sequential logjam surveys.

\begin{tabular}{|c|c|c|c|c|c|c|c|c|c|c|c|c|}
\hline \multirow[t]{2}{*}{ Location } & \multirow{2}{*}{$\begin{array}{l}\text { Floodplain } \\
\text { channel } \\
\text { distribution } \\
\text { type }\end{array}$} & \multirow{2}{*}{$\begin{array}{l}\text { Age of tilt } \\
\text { sprouts } \\
\text { (years) }\end{array}$} & \multicolumn{6}{|c|}{ Wood dams present in surveys } & \multirow[t]{2}{*}{$\begin{array}{l}\text { Chronology of } \\
\text { Logjams (years) }\end{array}$} & \multicolumn{3}{|c|}{$\begin{array}{l}\text { Minimum age of floodplain channels } \\
\text { from exposed, damaged roots }\end{array}$} \\
\hline & & & 1983 & 1991 & 1998 & 2002 & 2006 & 2008 & & Sample 1 & Sample 2 & Sample 3 \\
\hline HW SU 270077 & 3 & 15 & Partial & Partial & Active & Active & Active & Active & $\begin{array}{l}\text { Present }>23 \\
\text { Active }>8 \text { but }<15\end{array}$ & 11 & 8 & 6 \\
\hline OW SU 287039 & 3 & 6 & ns & Partial & ns & ns & Active & Active & $\begin{array}{l}\text { Present }>6 \\
\text { Active }<15\end{array}$ & 8 & $\mathrm{x}$ & 5 \\
\hline OW SU 287039 & 2 & 5 & ns & Partial & ns & ns & Active & Active & $\begin{array}{l}\text { Present }>5 \\
\text { Active }<15\end{array}$ & 2 & 2 & $\mathrm{n} / \mathrm{a}$ \\
\hline BW SU 257046 & 2 & $\mathrm{n} / \mathrm{a}$ & ns & None & ns & Active & Active & Comp. & Active $>4$ but $<15$ & ud & ud & $\mathrm{n} / \mathrm{a}$ \\
\hline BW SU 237066 & 1 or 2 & $\mathrm{n} / \mathrm{a}$ & ns & Comp. & ns & Active & Active & Comp. & Active $>4$ but $<15$ & $\mathrm{x}$ & 3 & $\mathrm{n} / \mathrm{a}$ \\
\hline BW SU 231091 & 2 & 23 & ns & Comp. & ns & Active & Active & Active & $\begin{array}{l}\text { Present }>23 \\
\text { Active }>4 \text { but }<15\end{array}$ & 8 & 15 & 7 \\
\hline HW SU 246111 & 1 & ns & None & None & None & Comp. & None & & None present & & ns & \\
\hline HW SU 247111 & 1 & 1 & None & Partial & None & None & Partial & & Partial $<4$ & & 1 & \\
\hline HW SU 246110 & 1 & & None & None & None & None & Comp. & & Complete $<4$ & & & \\
\hline HW SU 246110 & 1 & & Active & Partial & None & None & None & & None present & & & \\
\hline HW SU 246110 & 2 & & None & None & None & None & Comp. & & Complete $<4$ & & & \\
\hline HW SU 287044 & 1 & & None & None & None & None & None & & None present & & & \\
\hline HW SU 289042 & 1 & $\downarrow$ & None & None & None & Comp. & None & & None present & & $\downarrow$ & \\
\hline BW SU 232091 & 2 & & ns & Comp. & None & None & None & & None present & & & \\
\hline BW SU 232089 & 2 & & ns & None & None & Partial & Partial & & Partial $>4$ but $<8$ & & & \\
\hline BW SU 232088 & 1 & & ns & None & None & Partial & Comp. & & $\begin{array}{l}\text { Present }>8 \text { but }<15 \\
\text { Complete }<4\end{array}$ & & & \\
\hline BW SU 232085 & 1 & & ns & Comp. & None & None & Partial & & Partial $<4$ & & & \\
\hline BW SU 235081 & 2 & & ns & Partial & None & None & Partial & & Partial $<4$ & & & \\
\hline BW SU 256046 & 2 & & ns & None & None & Active & Comp. & & $\begin{array}{l}\text { Present }>4 \text { but }<8 \\
\text { Complete }<4\end{array}$ & & & \\
\hline
\end{tabular}

$\mathrm{ns}=$ not surveyed; $\mathrm{ud}=$ only undamaged exposed roots present; $\mathrm{x}=$ not possible to identify individual growth rings.

shown clearly in Fig. 10 for transects of sediment traps across a Type 3 floodplain. In both cases, the typical diffusion-based model for floodplain deposition that envisages an exponential reduction in overbank sedimentation with increasing distance from the main channel (Pizzuto, 1987; Walling et al., 1996) does not fully apply. Instead the presence of complex topography, hydraulically active dams and the network of floodplain channels creates a mosaic of depositional sites (Jeffries et al., 2003). Floodplain channels create routes for sediment laden water and through floodplain erosion, create new sources of sediment from within the floodplain. As a result floodplain channels are conduits for sediment, resulting in higher rates of deposition at sites distant from the main channel (Fig. 10). In these situations, overbank flooding may not occur but the transmission of water and sediment from the backwater upstream of the logjam, advects water and sediment down the floodplain channel network resulting in localized floodplain deposition.

Measured annual rates of floodplain sedimentation in this study were calculated by summing all the trap data for each transect and dividing by the total area of traps. This assumes that the traps are representative of the floodplain surface and that no change in trap efficiency occurs between sampling dates. Annual deposition rates upstream of logjams were always higher (1.2-8.2 times) than on the floodplain downstream of the dams. We converted the measured total annual deposition at individual traps into vertical accretion rates using the density of overbank deposits $\left(1855 \mathrm{~kg} \mathrm{~m}^{-3}\right)$. This yields values of annual floodplain vertical accretion of between 0.01 and $0.16 \mathrm{~m}$ at sites upstream of active logjams and $0-0.11 \mathrm{~m}$ downstream of them. Downstream of trees and other obstacles on the floodplain, rates of deposition are increased and average floodplain elevations are $0.12 \mathrm{~m}$ to $0.25 \mathrm{~m}$ above the local floodplain elevation. These values correspond with the vertical differences in floodplain surfaces across the floodplain. Variability in the elevation of floodplain surfaces shown in Fig. 3 ranges between 0.019 and $0.310 \mathrm{~m}$. In comparison the elevation differences due to floodplain channel formation range from 0.012 to $0.690 \mathrm{~m}$. The measured rates of vertical accretion, extrapolated over the typical age of active logjams can therefore explain the scales of floodplain topography, while the measured rates of floodplain erosion is generally of the same range.

\section{Discussion}

\subsection{Logjams and floodplain dynamics}

Logjams are important features that alter the local hydraulics and transport of sediment and wood within river systems. The processes associated with logjams vary according to the sediment transport regime and scale of river relative to logjam size. Moreover, the case study reported in this paper highlights the importance of logjam dynamics in mediating the location, duration and persistence of erosion and deposition on the floodplain surface.

In larger alluvial rivers logjams are important for blocking off secondary channels; deflecting flows into existing secondary channels and for maintaining floodplain dynamics via secondary channel processes (Abbe and Montgomery, 1996; Beechie et al., 2006). In addition, the formation of stable logjams within the main channel initiates sediment deposition and the development of islands (Gurnell et al., 2001; Montgomery and Piegay, 2003).

In smaller floodplain rivers, our observations show that logjammediated processes provide a mechanism of floodplain development that is distinct from those typically considered for humid temperate floodplains (Walling et al., 1996; Howard, 1996), but shares similarities with the logjam mediated patchwork floodplain model described by Montgomery and Abbe (2006). In their model, floodplain surfaces are formed from coarse bedload driven aggradation upstream of stable logjams. These surfaces are elevated above normal flood levels by the scale of the logjam, and as a result are relatively stable surfaces on which large trees can develop which in turn sustain logjam formation. The integrated effects of stable logjam formation result in morphologically complex floodplains that create a diverse range of physical habitats including side-channels. Brummer et al. (2006) go further and suggest that such logjam mediated aggradation 

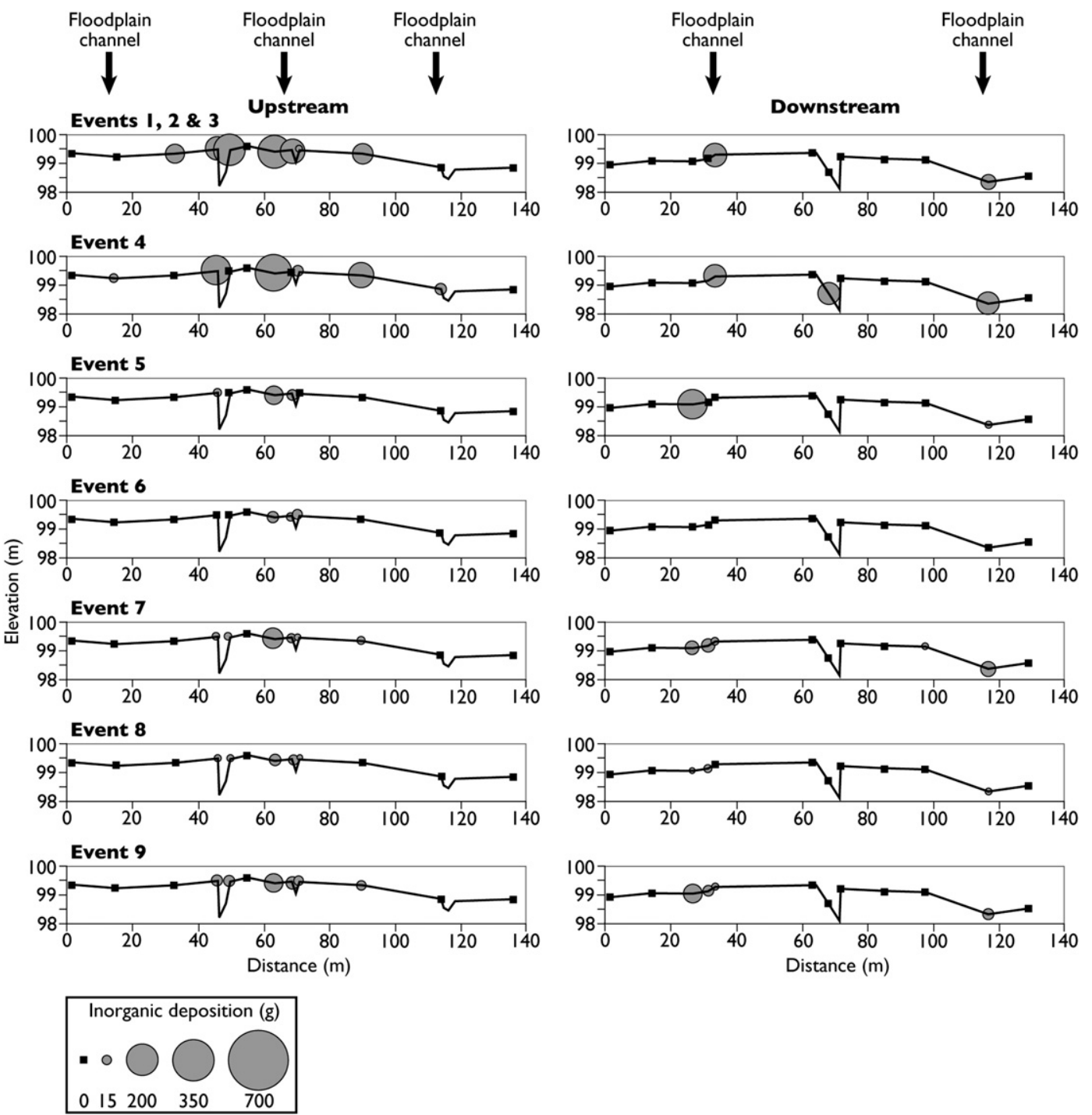

Fig. 10. Floodplain deposition for transects upstream and downstream of a hydraulically effective logjam, showing enhanced rats of deposition at sites distant from the main channel that result from advection of sediment laden water via floodplain channels.

promotes lateral channel adjustment in unconfined rivers and the reoccupation of former river channels.

In rivers with limited bedload transport like the case study streams, the floodplain surface evolves through the mediation of hydraulically effective logjams and the advection of suspended sediment laden flows over an otherwise stable forested floodplain surface. Locally high rates of deposition at the point of exit onto the floodplain build surfaces above the bankfull elevation close to the main channel, and above the general floodplain elevation along the margins of floodplain channels and downstream of obstacles on the floodplain. Flow concentration processes result in floodplain erosion and the progressive incision and the development of networks of floodplain channels. Thus sediment and particularly bedload transport regime represent an important control on logjam mediated channel:floodplain interaction. However, an additional control on this interaction is the dynamics of the logjams themselves. In the patchwork floodplain model of Montgomery and Abbe (2006) an important feature is the persistence and stability of the logjams (up to 1400 years) which promotes sediment accumulation and stability of the resulting floodplain surface. In contrast, the dynamics of the logjams in the case study stream are measured in less than 30 years in terms of location, and less than one year in terms of hydraulic effectiveness. Where logjams do persist, we observe the highest rates of floodplain vertical accretion (Jeffries et al., 2003; this study), and the formation of terraces and floodplain building in bedload dominated systems (Gurnell et al., 2001; Montgomery and Abbe, 2006). Similarly, stable logjams promote channel avulsion (Montgomery and Piegay, 2003), multiple channel patterns (Beechie et al., 2006; Montgomery and Abbe, 2006) and higher rates of floodplain incision within floodplain channels (this study). In contrast, dynamic logjams coupled with the mobility of organic materials on the floodplain result in spatial and temporal floodplain surface complexity, high rates of turnover, and the formation of complex surface topography. However, logjam dynamics coupled with the presence of root structures and cohesive sediments, mitigates against the formation of perennial floodplain secondary channels (Jones, 2006). Thus we consider logjam dynamics to be a fundamental control over the development of floodplain and channel geomorphology and associated physical habitat.

Logjam dynamics vary according to the size of the keystone logs (Abbe and Montgomery, 1996), the scale of the channel relative to log size, and hence stream order (Piégay and Gurnell, 1997), but also on the basis of wood decomposition rates and breakdown. The power of the channel relative to the mobility of the wood, and the mode of transport (congested or not - Braudrick et al., 1997) also determine the tendency for logjam formation and persistence. Therefore the 
ecology of the riparian forest is important since this controls the scale and type of large wood delivered to the river, and in deciduous forests such as the study streams, the seasonal delivery of leaves. Finally, the recruitment mechanism controls the location and volume of wood delivered to the channel. Stable logjams are most likely in old ( $>500$ years), coniferous forests located on lower order streams. Dynamic logjams are most likely in low order, young $(<100$ years $)$ deciduous woodlands with channel widths larger than maximum wood length. Logjam dynamics and associated floodplain and channel morphology will therefore be influenced by the management and composition of the riparian forest and the scale and bedload regime of the river.

\subsection{Logjams and the formation and maintenance of multiple channel patterns}

Multi-channel systems in European and North American landscapes are known to have been more widespread in the past (Brown, 2002; Walter and Merritts, 2008; Francis et al., 2008). The presence of multiple floodplain channel systems has been reported in other river types including island-braided (Collins and Montgomery, 2002; Montgomery and Abbe 2006), and meandering gravel-bed rivers (Piégay and Gurnell, 1997; Jones, 2006). Collins and Montgomery (2002) report that logjams are integral to maintaining channel pattern in a steep montane island-braided river with substantial bedload transport. In contrast, this study has identified the role of logjams and trees on the floodplain in the formation of a multichannel pattern template. We hypothesized that this process might be a potential mechanism, in the absence of substantial bed aggradation (see Brummer et al., 2006 model), for the formation of perennial multi-channel patterns. To test this hypothesis we assembled channel pattern data from a range of multi-channel river types (Table 3 ) and derived a suite of metrics that described the resulting planform. Examples were drawn from humid temperate hydroclimates. We then compared these to the pattern produced by the ephemeral channel network in the study streams. Reference to Table 3 shows differences between the planform characteristics of the study streams relative to other river types. Dynamic logjams in the case study rivers create more secondary channels and islands relative to other river pattern types. This is reflected in the large number of channel junctions and numbers of islands per unit valley length. If one assumes that the development from floodplain channel into a perennial channel would only occur in a few cases, rather than for all floodplain channels present, then the total number of islands, junctions and length-based metrics would be lower for the study streams (Table $3-2 / 3$ channel model). We modeled this by randomly sampling the total set of floodplain channels in both case study rivers to create a two and three-channel pattern. The resulting metrics are similar to those of island-braided systems. Despite this similarity, the process of channel bifurcation in multiple channel patterns can be quite different. A metric that distinguishes between active bed material driven channel branching and those created by overbank processes is the aspect ratio of islands and bars. Komar $(1983,1998)$ discusses the minimization of flow resistance of stream lined shapes with $\mathrm{L} / \mathrm{W}$ ratios of 3-4. These are typical of bars or islands formed by sediment transport processes. We hypothesized that the aspect ratio ( $\mathrm{L} / \mathrm{W})$ of islands or bars formed by bedload driven processes would more closely approximate to streamlined bars or islands, than those driven by overbank flood processes or avulsion. This hypothesis is supported by the data derived from the streams in Table 3 and represented in Fig. 11. The bars and islands of braided rivers tend to plot above a $\mathrm{L} / \mathrm{W}$ of 2 , with the majority plotting above a $\mathrm{L} / \mathrm{W}$ of 3 . In contrast island-braided and anastomosed channels tend to plot below the L/W threshold of 3 . The "islands" between channels in the Lymington river basin, plot below the $\mathrm{L} / \mathrm{W}$ threshold of 3 and despite differences in scale, overlap with anastomosed, island-braided and other floodplain channel multichannel planforms. Those of the two and three-channel model have aspect ratio's equivalent to island-braided and anastomosed channel patterns (Table 3 ).

We conclude that logjam mediated mechanisms can result in the formation of perennial multiple channel patterns. Based on the processes reported at the study sites, we identify the conditions required in the absence of high rates of bedload transport as; 1) position stable, hydraulically effective logjams and 2) longer and/or more frequent flood duration. The first criteria relates to the size and decomposition of large wood, which in the study streams is smaller than would naturally occur without management of the woodland and logjams. The second criteria controls the duration of overbank processes, and is controlled by geology, location in the basin and the proportion of precipitation falling as snow.

\subsection{Implications for river management and setting targets for floodplain restoration}

Wood and wood dynamics are an important control on channel and floodplain habitat influencing flood inundation frequency, extent and duration. In turn this influences opportunities for seed dispersal and vegetation colonization and succession (Gurnell et al., 2008). Rare invertebrate and amphibian communities occupy the temporary pools found in floodplain channels and pools resulting in high biodiversity (Nicolet, 1997; Davis et al., 2007), whilst perennial secondary channels are important nursery habitat for juvenile salmonids (Beechie et al., 2005). The resulting dynamic floodplain patchwork is analogous to the Shifting Habitat Mosaic that

Table 3

Comparisons between different metrics of channel pattern. Study river floodplain channel networks tend to have more channels per unit length. However when the ephemeral river network is simplified to 2-3 channels then metrics show overlap with anastomosed and island-braided pattern types.

\begin{tabular}{|c|c|c|c|c|c|c|c|c|c|}
\hline & Channel type & $\begin{array}{l}\text { Reach length } \\
\text { (m) }\end{array}$ & $\begin{array}{l}\text { Total } \\
\text { sinuosity }\end{array}$ & Confinement & $\begin{array}{l}\text { No. } \\
\text { islands }\end{array}$ & $\begin{array}{l}\text { No. islands/ } \\
\text { valley length }\end{array}$ & $\begin{array}{l}\text { Mean } \mathrm{L} / \mathrm{W} \\
\text { ratio }\end{array}$ & $\begin{array}{l}\text { Braiding Index } \\
\text { (Brice, 1960) }\end{array}$ & $\begin{array}{l}\text { No. } \\
\text { junctions }\end{array}$ \\
\hline BW reach & Meandering FPC & 995 & 3.20 & 22.6 & 28 & 0.028 & 1.7 & 1.67 & 56 \\
\hline HW reach & Meandering FPC & 861 & 4.50 & 26.7 & 25 & 0.029 & 1.7 & 1.75 & 64 \\
\hline BW reach (2-3 channel model) & Meandering FPC & 995 & 2.40 & 22.6 & 10 & 0.011 & 2.02 & 1.41 & 20 \\
\hline HW reach ( $2-3$ channel model) & Meandering FPC & 861 & 3.06 & 26.7 & 10 & 0.012 & 2.40 & 1.59 & 20 \\
\hline Dosewallips (Jones (2006)) & Sinuous FPC & 2852 & 3.63 & 9.8 & 24 & 0.008 & 2.2 & 2.13 & 39 \\
\hline Gearagh & Island-braided & 1050 & 12.0 & 16 & 134 & 0.128 & 2.98 & 3.18 & 130 \\
\hline Hoh & Island-braided & 4971 & 2.92 & 7.3 & 17 & 0.003 & 2.36 & 1.36 & 41 \\
\hline Queets Abbe and Montgomery (2003) & Island-braided & 1030 & 6.72 & 8.7 & 25 & 0.024 & 2.77 & 4.27 & 68 \\
\hline Skagit & Island-braided & 8188 & 3.75 & 6.2 & 13 & 0.002 & 1.85 & 1.46 & 20 \\
\hline Rakaia & Braided & 11,600 & 3.02 & 8.3 & 24 & 0.002 & 2.94 & 1.58 & 23 \\
\hline Tagliamento & Braided & 5962 & 2.43 & 6.6 & 22 & 0.004 & 3.17 & 1.67 & 54 \\
\hline Culm & Anastomosed & 3348 & 3.80 & 64.8 & 6 & 0.002 & 1.98 & 1.46 & 10 \\
\hline Hvita & Anastomosed & 10,362 & 2.89 & 5.6 & 22 & 0.002 & 2.16 & 1.03 & 48 \\
\hline
\end{tabular}

Total sinuosity (Richards, 1982) = total channel length/valley length, Confinement = Valley width / channel bankfull width, Brice (1960) Braiding Index $=2$ (Length of all bars and islands)/Centreline length. 


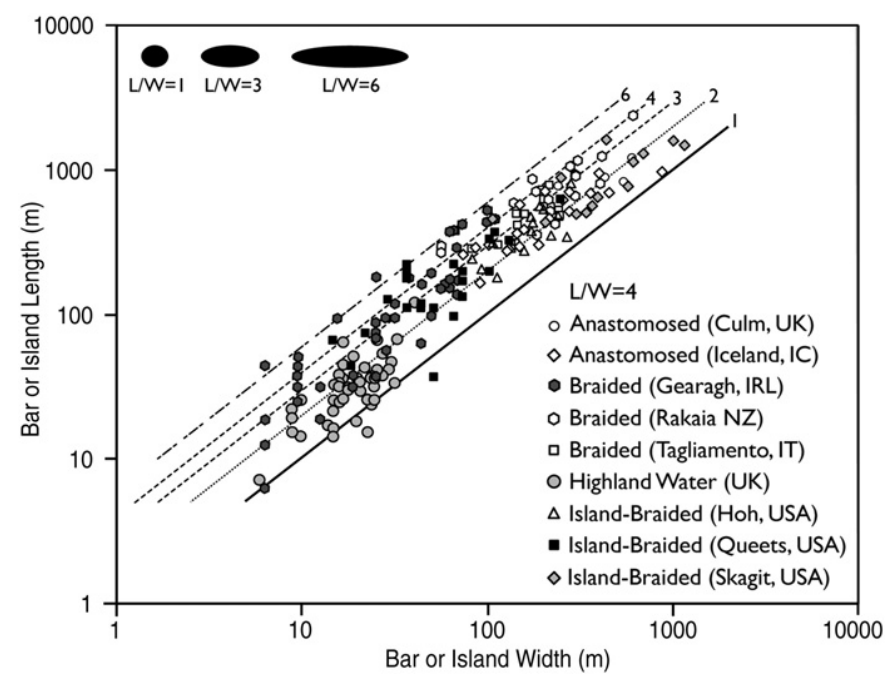

Fig. 11. Island shape for a range of multi-channel patterns. Floodplain channel island patterns occupy the same range of $\mathrm{L} / \mathrm{W}$ as anastomosed and island-braided planforms and are differentiated from islands formed by sediment transport processes. Avulsion driven island formation does not result in streamlined shapes, hence the overlap.

characterizes large piedmont alluvial floodplains and is associated with high biodiversity (Stanford et al., 2005; Davis et al., 2007). Similarly, Beechie et al. (2006) have associated laterally stable channels with low biodiversity as a result of the low turnover rates of floodplain material. The presence of logjams in alluvial bedload sufficient channels creates stable hardpoints that force channel migration but also create stable elevated floodplain surfaces. In bedload limited channels with mature forest, logjams create foci for flow and suspended sediment avulsion, resulting in highly dynamic floodplain surfaces yet a canopy that is relatively old. This model of smaller floodplain rivers differs from contemporary models of singlethreaded laterally stable meandering rivers that are typically the target selected for river restoration (Kondolf, 2006). Instead, this study accords with Brown (2002) and Walter and Merritts (2008) in calling for reconsideration of the assumptions underpinning lowland headwater river restoration and to recognize the role of logjams in controlling both in-channel as well as floodplain habitat dynamics.

\subsubsection{Long term dynamics and floodplain evolution}

The role of logjams in the development of floodplain surfaces and river channel pattern presents challenges for the interpretation of alluvial sedimentary sequences. Rapid localized alluviation and avulsion are associated with stable logjams in the presence of sediment loads. Thus periods of increased wood loading (and in particular large wood recruitment) and increased sediment loads can be expected to result in dynamic channel and floodplain processes, characterized by secondary/floodplain channel formation and floodplain accretion. Under these conditions, channel blocking and infilling would be rapid, resulting in a shifting habitat mosaic (sensu Stanford et al., 2005) across the floodplain. In contrast, periods of low wood recruitment and supply limited transport result in channel incision, relatively stable floodplain surfaces, low rates of vertical accretion and simplification of channel pattern. Brown (2002), Gregory (2003) and more recently, Francis et al. (2008) have highlighted how the role of wood in rivers has changed in response to human modification of the riparian corridor and channel form. Similarly, Coulthard and Macklin (2001) have demonstrated how substantial increases in sediment load occurs in response to both human landscape disturbance and climate change (though without the inclusion of wood in rivers). Therefore the evolution of floodplain surfaces over the Holocene is likely to have been mediated not only by vegetation processes (colonization and clearance of riparian and exposed sedimentary surfaces) and sediment supply, but also by the formation and dynamics of logjams and their interaction with phases of increasing and decreasing wood and sediment transport.

\section{Conclusion}

This study has demonstrated the important role of wood in the evolution of complex floodplain topography. Important differences are evident between bedload and suspended load driven floodplain: channel systems. In bedload systems, aggradation upstream of log jams elevates the channel and can build floodplain surfaces. Aggradation behind wood dams also drives lateral migration and the formation of multiple channels through channel blocking and avulsion. In channels with limited bedload supply and transport, floodplain development is controlled by vertical accretion and incision on the floodplain surface. Wood in these rivers creates local points of flow avulsion and enhanced overbank sedimentation. Interaction with floodplain vegetation creates a dynamic patchwork of depositional surfaces and zones of floodplain scour. Channelization of flows between vegetation, deposits and tree roots systems creates localized concentration of overbank flows. In turn these lead to scour and the evolution of floodplain channels. The network of floodplain channels acts to distribute water, fine sediment and organic matter over the wider floodplain, and creates routes for floodplain organic matter back into the main river. The dynamics of these systems is strongly controlled by the formation, development and collapse of channel-spanning logjams, and by the mobility of large wood and organic matter accumulations on the floodplain surface. In the study streams, lack of bed aggradation and the mobility of debris, coupled with the protection afforded by extensive root systems limit the development of perennial floodplain channels. However, the resulting channel pattern overlaps with other avulsion driven river systems and is therefore considered to be a mechanism for the formation of multiple channel patterns. The influence of logjams on floodplain geomorphology and physical habitat in rivers with and without large bedload transport presents different targets for restoration, and demonstrates that management of riparian woodland and wood within the channel is an important mechanism for re-establishing dynamic channel:floodplain interactions. The longer term role of logjams in mediating floodplain processes and channel evolution over the Holocene requires further research particularly in relation to the prevalence of logjams, the characteristics of the stratigraphic record associated with logjams, and their relationship with multiple channel patterns.

\section{Acknowledgements}

The authors would like to acknowledge the support of the EU LIFE III project and in particular funding from the Environment Agency (Maxine Elliott and Tim Holzer). In addition some of the work was funded by Forest Research (Tom Nisbet) for which we gratefully acknowledge their contribution. The comparison between the role of logjams in different river systems benefitted from discussions with Dave Montgomery, Tom Lisle, Tim Beechie and George Pess.

\section{References}

Abbe, T.B., Montgomery, D.R., 1996. Large woody debris jams, channel hydraulics and habitat formation in large rivers. Regulated Rivers: Research and Management 12, 201-221.

Abbe, T.B., Montgomery, D.R., 2003. Patterns and processes of wood debris accumulation in the Queets river basin, Washington. Geomorphology 51, 81-107. Amoros, C., Petts, G.E. (Eds.), 1993. Hydrosystems Fluviaux. Masson, Paris.

Bathurst, J.C., Thorne, C.R., Hey, R.D., 1977. Direct measurements of secondary currents in river bends. Nature 269, 504-506.

Beechie, T.J., Liermann, M., Beamer, E.M., Henderson, R., 2005. A classification of habitat types in a large river and their use by juvenile salmonids. Transactions of the American Fisheries Society 134, 717-729. 
Beechie, T.J., Liermann, M., Pollock, M.M., Baker, S., Davies, J., 2006. Channel pattern and riverfloodplain dynamics in forested mountain river systems. Geomorphology 78 (1-2) 124-141.

Bodoque, J.M., Diez-Herrero, A., Martin-Duque, J.F., Rubiales, J.M., Godfrey, A., Pedraza, J., Carrasco, R.M., Sanz, M.A., 2005. Sheet erosion rates determined by using dendrogeomorphological analysis of exposed tree roots: two examples from Central Spain. Catena 64, 81-102.

Braudrick, C.A., Grant, G.E., Ishikawa, Y., Ikeda, H., 1997. Dynamics of wood transport in streams: a flume experiment. Earth Surface Processes and Landforms 22, 669-683.

Brayshaw, A.C., Frostick, L.E., Reid, I., 1983. The hydrodynamics of particle clusters and sediment entrainment in coarse alluvial channels. Sedimentology 30, 137-143.

Brown, A.G., 1997. Alluvial Geoarchaeology: Floodplain Archaeology and Environmental Change. Cambridge University Press, Cambridge.

Brown, A.G., 2002. Learning from the past: palaeohydrology and palaeoecology. Freshwater Biology 47, 817-829.

Brummer, C.J., Abbe, T.B., Sampson, J.R., Montgomery, D.R., 2006. Influence of vertical channel change associated with wood accumulations on delineating channel migration zones, Washington, USA. Geomorphology 80, 295-309.

Brice, J.C., 1960. Index for description of channel braiding. Bulletin of Geological Society of America 71, 1833

Collins, B.D., Montgomery, D.R., 2002. Forest development, wood jams, and restoration of floodplain rivers in the Puget Lowland, Washington. Restoration Ecology 10 , 237-247.

Coulthard, T.J., Macklin, M.G., 2001. How sensitive are river systems to climate and land-use changes? A model-based evaluation. Journal of Quaternary Science 16 (4) 247-351.

Curran, J.H., Wohl, E.E., 2003. Large woody debris and flow resistance in step-pool channels, Cascade Range, Washington. Geomorphology 51 (1-3), 141.

Davis, S.R., Brown, A.G., Dinnin, M.H., 2007. Floodplain connectivity, disturbance and change: a palaeoentomological investigation of floodplain ecology from SW England. Journal of Animal Ecology 76, 276-288.

Davis, R.J., Gregory, K.J., 1994. A new distinct mechanism of river bank erosion in a forested catchment. Journal of Hydrology 157, 1-11.

Francis, R.J., Petts, G.E., Gurnell, A.M., 2008. Wood as a driver of past landscape change along river corridors. Earth Surface Processes and Landforms 33, 1622-1626.

Friedman, J.M., Vincent, K.R., Shafroth, P.B., 2005. Dating floodplain sediments using tree-ring response burial. Earth Surface Processes and Landforms 30, 1077-1091.

Gärtner, H., 2007. Tree roots - methodological review and new development in dating and quantifying erosive processes. Geomorphology 86, 243-251.

Gay, G.R., Gay, H.H., Gay, H.W., Martinson, H.A., Meade, R.H., Moody, J.A., 1998 Evolution of cutoffs across meander necks in Powder River, Montana, USA. Earth Surface Processes and Landforms 23, 651-662.

Gippel, C.J., 1995. Environmental hydraulics of large woody debris in streams and rivers. Journal of Environmental Engineering, ASCE 121, 388-395.

Gregory, K.J., 1992. Vegetation and river channel process interactions. In: Boon, P.J. Calow, P., Petts, G. (Eds.), River Conservation and Management. Wiley, Chichester, pp. 255-269.

Gregory, K.J., 2003. The limits of wood in world rivers: present, past and future. In: Gregory, G., Boyer, K., Gurnell, A. (Eds.), The Ecology and Management of Wood in World Rivers: American Fisheries Society Symposium, 37, pp. 1-19.

Gregory, K.J., Gurnell, A.M., Hill, C.T., 1985. The permanence of debris dams related to river channel processes. Hydrological Sciences 30, 371-381.

Gregory, K.J., Davis, R.J., Tooth, S., 1993. Spatial distribution of coarse woody debris dams in the Lymington Basin, Hampshire, UK. Geomorphology 6, 207-224.

Gurnell, A.M., Sweet, R., 1998. The distribution of large wood accumulations and pools in relation to woodland stream management in a small, low-gradient stream. Earth Surface Processes and Landforms 23, 1101-1121.

Gurnell, A.M., Petts, G.E., Hannah, D.M., Smith, B.P.G., Edwards, P.J., Kollmann, J., Ward, J.V Tockner, K., 2001. Riparian vegetation and island formation along the gravel-bed Fiume Tagliamento, Italy. Earth Surface Processes and Landforms 26, 31-62.

Gurnell, A.M., Thompson, K., Goodson, J., Moggridge, H., 2008. Propagule deposition along river margins: linking hydrology and ecology. Journal of Ecology 96, 553-565.

Harwood, K., Brown, A.G., 1993. 'Fluvial processes in a forested anastomosing river: flood partitioning and changing flow patterns'. Earth Surface Processes and Landforms 18, 741-748.

Hey, R.D., 1979. Flow resistance in gravel-bed rivers. Proceedings of the American Society of Civil Engineers: Journal of Hydraulic Engineering, vol. 109(6), pp. 842-851.

Howard, A.D., 1996. Modelling channel evolution and floodplain morphology. In: Anderson, M.G., Walling, D.E., Bates, P.D. (Eds.), Floodplain Processes. Wiley, Chichester, pp. 15-61.

Hupp, C.R., 1990. A dendrogeomorphic approach to establishing slope retreat, Maxey Flats, Kentucky. Geology 18, 658-661.

Jeffries, R., 2002. 'The effect of woody vegetation on the geomorphology of a lowland floodplain: a study of a basin in southern England'. PhD thesis, University of Southampton. 270p

Jeffries, R., Darby, S.E., Sear, D.A., 2003. 'The influence of vegetation and organic debris on flood-plain sediment dynamics: case study of a low-order stream in the New Forest, England'. Geomorphology 51, 61-80.

Jones, J.L., 2006. Side channel mapping and fish habitat suitability analysis using LiDAR topography and orthophotography. Photogrammetric Engineering and Remote Sensing 1202-1206 November.

Keller, E.A., MacDonald, A., Tally, T., Merrit, N.J., 1995. Effects of large organic debris on channel morphology and sediment storage in selected tributaries of Redwood Creek, northwestern California. USGS Professional Paper, pp. 1-29.

Komar, P.D., 1983. Shapes of streamlines islands on Earth and Mars, experiments and analyses of the minimum-drag form. Geology 11, 651-654.
Komar, P.D., 1998. Cataclysmic floods on Earth and Mars - morphology and hydraulic interpretations. In: Klingeman, P.C., Beschta, R.L., Komar, P.D., Bradley, J.B. (Eds.), Gravel-bed Rivers in the Environment. Water Resources Publications, Colorado, USA, pp. 677-704.

Kondolf, G.M., 2006. River restoration and meanders. Ecology and Society 11 (2), 42-60.

Lawler, D.M. Thorne, C.R. Hooke, J.M. 1997. Bank erosion and instability. In: Thorne, C.R Hey, R.D., Newson, M.D. (Eds.), Applied Fluvial Geomorphology for River Engineering and Management. Wiley, Chichester, pp. 137-167.

Malik, I., 2006. Contribution to understanding the historical evolution of meandering rivers using dendrochronological methods: example of the Maa Panew River in southern Poland. Earth Surface Processes and Landforms 10, 1227-1245.

Manners, R.B., Doyle, M.W., 2008. A mechanistic model of woody debris jam evolution and its application to wood based restoration and management. River Research and Applications 24, 1104-1123.

Marston, R.A., Girel, J., Pautou, G., Piégay, H., Bravard, J.P., Arneson, C., 1995. Channel metamorphosis, floodplain disturbance, and vegetation development: Ain River France. Geomorphology 13, 121-131.

McKenny, R., Jacobson, R.B., Wertheimer, R.C., 1995. Woody vegetation and channel morphogenesis in low-gradient, gravel-bed streams in the Ozark Plateaus, Missouri and Arkansas. Geomorphology 13, 175-198.

Millington, C.E., 2007. 'The geomorphological dynamics of a restored forested floodplain'. PhD thesis, University of Southampton. 280p.

Millington, C.E., Sear, D.A., 2007. Impacts of restoration on small wood dynamics in a low gradient headwater stream. Earth Surface Processes and Landforms 37 (8), 121-133.

Mizugakia, S., Nakamurab, F., Arayab, T., 2006. Using dendrogeomorphology and ${ }^{137} \mathrm{Cs}$ and ${ }^{210} \mathrm{~Pb}$ radiochronology to estimate recent changes in sedimentation rates in Kushiro Mire, Northern Japan, resulting from land use change and rive channelization. Catena 68, 25-40.

Montgomery, D.R., Buffington, J.M., 1997. Channel-reach morphology in mountain drainage basins. Geological Society of America Bulletin 109, 596-611.

Montgomery, D.R., Piegay, H., 2003. Editorial - Wood in rivers: interactions with channel morphology and processes. Geomorphology 51, 1-5.

Montgomery, D.R., Abbe, T.B., 2006. Influence of logjam-formed hard points on the formation of valley-bottom landforms in an old-growth forest valley, Queets River, Washington, USA. Quaternary Research 65, 147-147.

Montgomery, D.R., Buffington, J.M., Smith, R.D., Schmidt, K.M., Pess, G., 1995. Pool spacing in forest channels. Water Resources Research 31, 1097-1105.

Montgomery, D.R., Collins, B.D., Abbe, T.B., Buffington, J.M., 2003. Geomorphic effects of wood in rivers. In: Gregory, S.V Boyer, K.L Gurnell, A.M. (Eds.), The Ecology and Management of Wood in World Rivers. American Fisheries Society, Bethesda, Maryland, pp. 21-47.

Naiman, R.J., Decamps, H.D., Pollock, M., 1993. The role of riparian corridors in maintaining regional biodiversity. Ecological Applications 3, 209-212.

Nakamura, F., Swanson, F.J., 1994. Distribution of coarse woody debris in a mountain stream, western Cascade Range, Oregon. Canadian Journal of Forest Research 24 2395-2403.

Nicholas, A.P., Walling, D.E., 1995. Modelling contemporary overbank sedimentation on floodplains: some preliminary results. In: Hickin, E.J. (Ed.), River Geomorphology. Wiley, Chichester, pp. 131-153.

Nicolet, P., 1997. A comparison of biotic assemblages in freshwater bodies in a seminatural area of lowland Britain (The New Forest, Hampshire), and implications fo conservation. Unpublished MSc Dissertation, Oxfrod Brookes University, 73p.

O'Connor, J.E., Jones, M.A., Haluska, T.L., 2003. Flood plain and channel dynamics of the Quinault and Queets Rivers, Washington, USA. Geomorphology 51, 31-59.

Peterken, G.F., Spencer, J.W., Field, A.B., 1996. Maintaining the ancient and ornamenta woodlands of the New Forest, unpublished Consultation Document, Forestry Commission, Lyndhurst, UK.

Piégay, H., 1997. Interactions between floodplain forests and overbank flows: data from three piedmont rivers in southeastern France. Global Ecology and Biogeography Letters 6, 187-196.

Piégay, H., Gurnell, A.M., 1997. Large woody debris and river geomorphological pattern: examples from S.E. France and S. England. Geomorphology 19, 99-116.

Piégay, H., Marston, R.A., 1998. Distribution of large woody debris along the outer bend of meanders in the Ain River, France. Physical Geography 19, 318-340.

Piégay, H., Citterio, A., Astrade, L., 1998. Interactions between large woody debris and meander cut-off (example of Mollon reach on the Ain River, France). Zeitschrift Fur Geomorphologie 42, 187-208.

Pizzuto, J.E., 1987. Sediment diffusion during overbank flows. Sedimentology 34, 301-317.

Richards, K.S., 1982. Rivers: Form and Process in Alluvial Channels. Methuen, London. 290 p.

Richards, K.S., Clifford, N.J., 1991. Fluvial geomorphology: structured beds in gravelly rivers. Progress in Physical Geography 15 (4), 407-422.

Rodwell, J.S. (Ed.), 1991. British Plant Communities. Volume 1. Woodlands and scrub. Cambridge University Press, Cambridge. 117p.

Sear, D.A., Kitts, D.R., Millington, C.E., 2006. New Forest LIFE-III monitoring report. The Geomorphic and Hydrological Response of New Forest Streams to River Restoration. Available online:http://www.newforestlife.org.uk/life3/PDFs/PDFs/ 9.16Geomorphological MonitoringReport.pdf (Accessed 2009, February 21.

Smith, R.D., Sidle, R.C., Porter, P.E., 1993. Effects on bedload transport of experimental removal of woody debris from a forest gravel-bed stream. Earth Surface Processes and Landforms 18, 455-468.

Stanford, J.A., Lorang, M.S., Hauer, F.R., 2005. The shifting habitat mosaic of river ecosystems. Verh. Internat. Verein. Limnol. 29 (1), 123-136.

Steiger, J., Gurnell, A.M., Petts, G.E., 2001. Sediment deposition along the channel margins of a reach of the middle River Severn, UK. Regulated Rivers: Research and Management 17, 443-460. 
Strunk, H., 1997. Dating of geomorphological processes using dendrogeomorphological methods. Catena 31, 137-151.

Thompson, D.M., 2003. A geomorphic explanation for a meander cutoff following channel relocation of a coarse-bedded river. Environmental Management 31, 385-400.

Tubbs, C.R., 2001. The New Forest: History, Ecology and Conservation. New Forest Ninth Century Trust, New Forest Museum, Lyndhurst, Hampshire, UK.

Tuckfield, C.G., 1980. Stream channel stability and forest drainage in the New Forest, Hampshire. Earth Surface Processes 5, 317-329.

Vandekerckhove, L., Muys, B., Poesen, J., De Weerdt, B., Coppé, N., 2001. A method for dendrochronological assessment of medium-term gully erosion rates. Catena 45 , 123-161.
Walling, D.E., He, Q., Nicholas, A.P., 1996. Floodplains as suspended sediment sinks. In: Anderson, M.G., Walling, D.E., Bates, P.D. (Eds.), Floodplain Processes. Chichester, Wiley, pp. 299-440

Walter, R.C., Merritts, D.J., 2008. Natural streams and the legacy of water-powered mills. Science 319, 299-304

Ward, J.V., Tockner, K., Uehlinger, U., Malard, F., 2001. Understanding natural patterns and processes in river corridors as the basis for effective river restoration. Regulated Rivers: Research and Management 17, 311-323. 